\title{
SANGRIA POR PUNTURA NO CULTIVAR RRIM 600 NO PLANALTO PAULISTA
}

\author{
ADONIAS DE CASTRO VIRGENS FILHO
}

Orientador: Prof. PAULO ROBERTO DE CAMARGO E CASTRO

Dissertação apresentada à Escola Superior de Agricultura "Luiz de Queiroz", da Universidade de São Paulo, para obtenção do Título de Mestre em Agronomia; Área de Concentração; Fitotecnia,

$P|R A C| C A B A$

Estado de São Paulo - Brasil

Agosto -1986 
Aos Drs. DJALMA BATISTA BAHIA (In memorian)

e. ANTONIO LEMOS MAIA (In memorian), pelos relevantes serviços prestados a Heveicultura do Brasil,

HOMENAGEM

Aos meus sobrinhos: PRYSCILA (In memorian), ELMO (In memorian) e DEBORA (In memorian)

OFEREÇO.

A minha esposa e filhas, Aos meus pais, Aos meus irmãos,

DEDICO. 


\section{AGRADECIMENTOS}

Ao Dr. Paulo Roberto de Camargo e Castro pela valiosa orientação e amizade.

A Comissão Executiva do Plano da Lavoura Cacaueira (CEPLAC) pela oportunidade oferecida para a realização deste curso .

Aos Convēnios EMBRAPA/FEALQ e FINEP/FEALQ por facilitarem os recursos à condução do experimento.

Ao Dr. Vicente Haroldo de F. Moraes pelas importantes suges tões.

Aos Srs. Kenzo Haiashi e Kazuiro Haiashi pelo apoio na condü ção do experimento.

Aos Drs. Gabriel Adriān Sarriés e Décio Barbin pela orientação e colaboração na anälise estatística.

Ao Centro Nacional de Pesquisas de Seringueira e Dendẽ (CNPSD-EMBRAPA) pelo apoio e colaboração no fornecimento de literatura, e em particular ao Sr. Antonio P. Serzede lo pela anälise de casca em laboratörio.

Aos. Drs. Paulo Fernando de Brito, José Fernando Canuto Benesi, José Dias da Costa e Urala Waidyanatha pelo apoio prestado.

A ESALQ pela contribuição à nossa formação.

A todos aqueles que direta ou indiretamente contribuiram para a realização deste trabalho. 
Pägina

RESUMO $\ldots \ldots \ldots \ldots \ldots \ldots \ldots \ldots \ldots \ldots \ldots \ldots \ldots \ldots \ldots \ldots \ldots \ldots$

SUMMARY $\ldots \ldots \ldots \ldots \ldots \ldots \ldots \ldots \ldots \ldots \ldots \ldots \ldots \ldots \ldots \ldots \ldots \ldots$

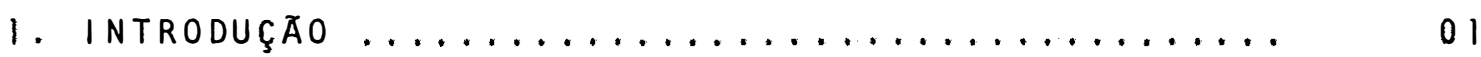

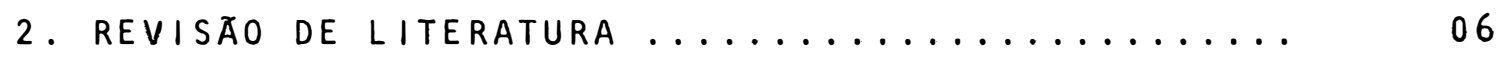

2.1. Sangria por puntura e o uso de estimulantes 08

2.2. Aspectos relacionados com a ärea de drena-

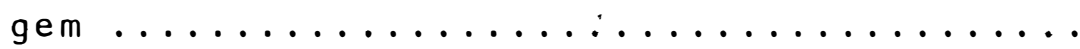

2.2.1. Comprimentos de faixa ........... 14

2.2.2. Largura de faixa ............. 15

2.2.3. Altura de localização das faixas... 16

2.2.4. Nümero de furos .............. 17

2.2 .5 . Profundidade de incisão .......... 18

2.3. Reações anatômicas a SPP ............... 18

2.3.1. Espocamento de casca ............ 19

2.3 .2 . Inchaço ................... 20

2.3.3. Fendilhamento de casca.......... 21

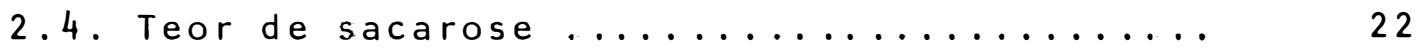

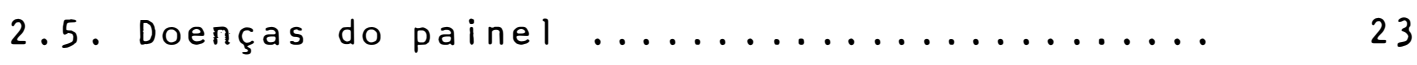

2.6. Efeitos no crescimento e produção ......... 27

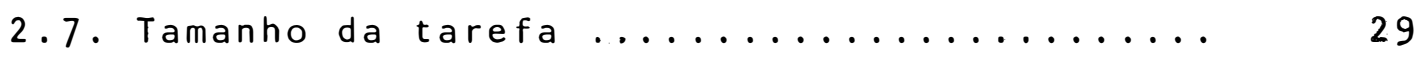

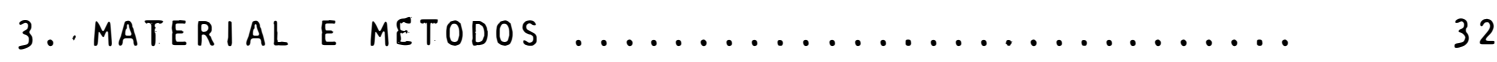

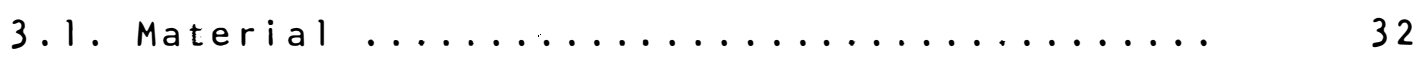

3.1 .1 Localização e clima ............. 32

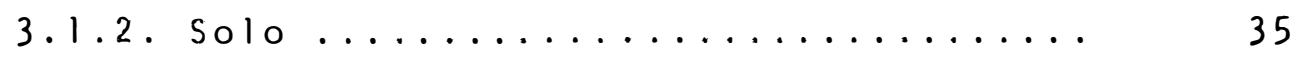

3.1 .3 . Material botânico ............. 38 
Pàgina

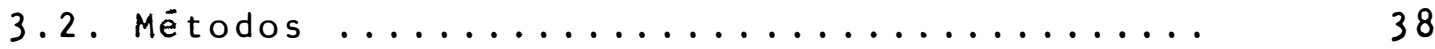

3.2.1. Instalação do plantio ........... 38

3.2.2. Condução do plantio ............ 39

3.2.3. Delineamento experimental ........ 40

3.2.4. Tratamentos ................. 40

3.2.5. Instalação e condução do experimento 42

3.2.6. Anälise estatística ............ 45

3.2 .6 .1 . Estudo de correlação ..... 47

4. RESULTADOS E DISCUSSÃO ................. 48

4.1. Produção de borracha ................. 48

4.1.1. Variações mensais na produção ...... 53

4.1.2. Variação semanal na produção ....... 54

4.1.3. Influência da concentração do estimü lante, nümero de punturas e comprimento de faixa na produção .........

56

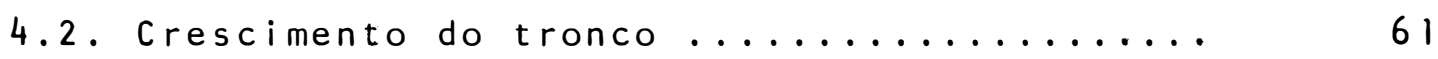

4.3. Correlação entre a produção e o crescimen-

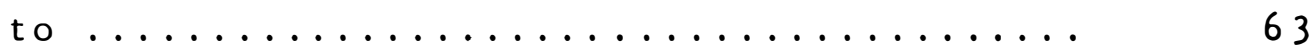

4.4. Conteūdo de borracha seca (DRC) .......... 65

4.5. Reações da casca ao método de sangria..... 66

4.5.1. Espocamento de casca ........... 66

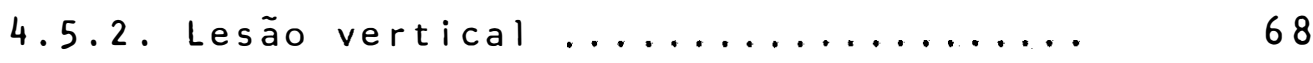

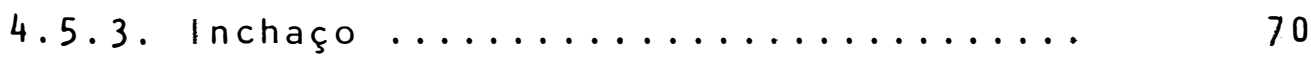

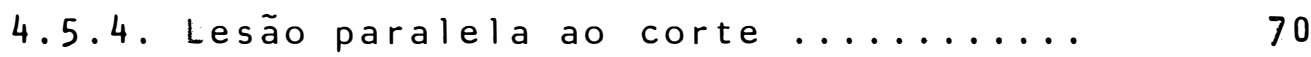

4.5.5. Regeneração de casca ................ 71

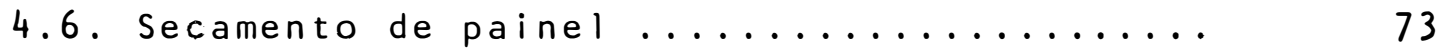

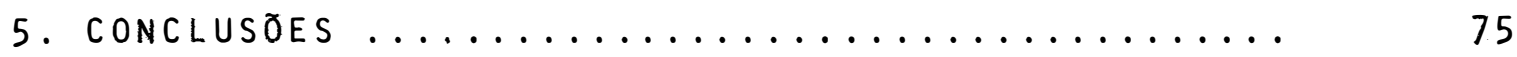

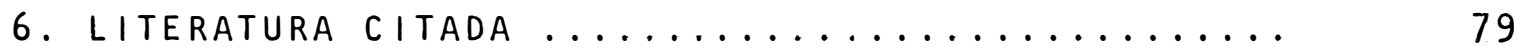


FIGURA N

Pàgina

01

Resultados de balanços hídricos decendiais, referentes aos anos de 1963 e 1985 e médios (normais), para Ribeirão

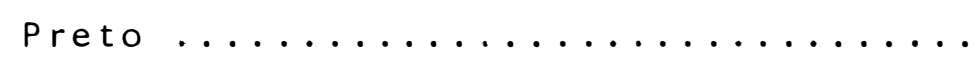

02

Representação dos tratamentos utiliza-

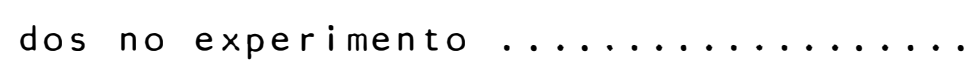

a - Abertura de faixas na SPP; b-aplicação do estimulante; c - instrumento utilizado na realização das puntú ras; d - visão do painel de explora-

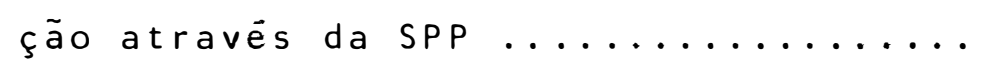

44

04 Produção em gramas de borracha por plan ta e por sangria (média de 11 meses).

a - espocamento de casca; b - lesão ao longo do painel da SPP; c - secamento de painel .................... 
TABELA N:

Pàgina

01

Dados climäticos registrados na unidade de observação mais pröxima do local do experimento (Bebedouro, $S P$ ), no periodo

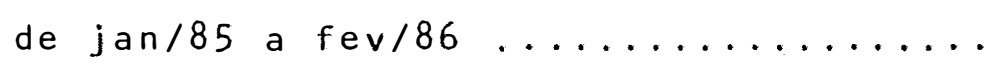

02

Anälise granulométrica da amostra de so lo coletada no local do experimento...

03

Anālise química da amostra de solo cole tada no local do experimento .........

04

Esquema dos tratamentos utilizados no

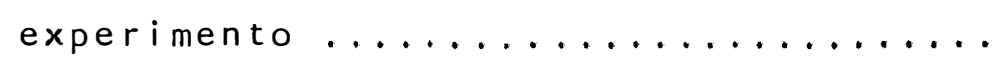

05 Esquema da anälise de variância emprega do para analisar separadamente a produ ção e o crescimento do tronco .........

06 Esquema da anälise de variància emprega do para estudo de interação entre os ca racteres envolvidos na sangria por puntura em relação à produção ...........

07 Anälise de variância para mëdias de pro dução de borracha seca (g/sangria/planta), envolvendo os sistemas de sangria por puntura e sangria convencional ....

Teste de Tukey para anālise de tratamentos em relação a produção de borracha ..... 
09 Estimativa da produção de borracha em relação ao método de sangria .........

10 Anālise de variância para produção de borracha (g/sangria/planta), envolvendo os tratamentos da sangria por puntu$r a \ldots \ldots \ldots \ldots \ldots \ldots \ldots \ldots$

11 Produção de borracha em g/sangria obti da em plantas do cultivar RRIM 600 submetidas à sangria por puntura em Colina - SP. Comparações de médias entre diferentes fatores e variäveis ..........

12 Anālise de variància para incremento no perímetro do tronco em cm (fev/85 a fev/

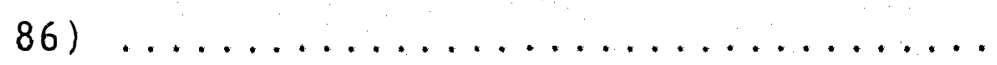

13 Testede Tukey para mëdias detratamentos em relação ao incremento no perímetro do tronco ( $c m)$ envolvendo todos os trata-

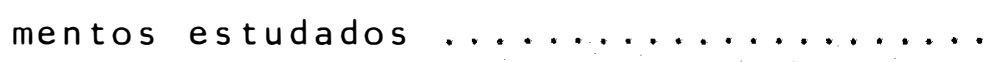

14 Estudo de correlação entre os parâmetros: produção e crescimento do tronco.

15 Conteüdo de borracha seca no lätex (DRC) em relação aos diferentes mëtodos de sangria $\ldots \ldots \ldots \ldots \ldots \ldots \ldots \ldots \ldots$ 
TABELA No

Situação dos painēis de sangria aos 11

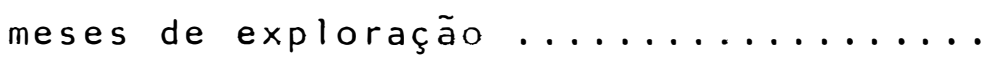

Análise de amostras de casca registrą das no painel de sangria à altura de 1,0

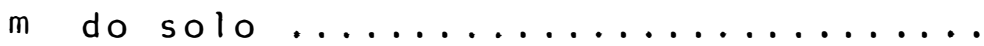




\section{Autor: ADONIAS DE CASTRO VIRGENS FILHO}

Orientador: Prof. Dr. PAULO ROBERTO DE CAMARGO E CASTRO

\section{RESUMO}

0 periodo existente entre o plantio e o inicio de exploração da seringueira (Hevea sp.) tem uma duração em torno de 5 a 7 anos, podendo em alguns casos ser um pouco mais prolongado. Este fato torna pouco atrativa a realização de um empreendimento heveícola, pois para pleno êxito do investimento, deve-se proceder a exploração das plantas, sem prejuízo do seu crescimento. 0 sistema de extração do látex ado tado no planalto Paulista e numa grande parcela dos centros produtores de borracha $\vec{e}$ a sangria em $1 / 2 \mathrm{~s} d / 26 \mathrm{~d} / 7$, a qual, demanda mão-de-obra intensiva e especializada, o que nem sempre se encontra disponível em qualidade e quantidade suficien tes. Estes dois aspectos têm motivado a realização de estudos no sentido de se obter um sistema que possibilite a antecipação do período de imaturidade econômica da cultura, com exigência de mão-de-obra menos tecnificada e com maior rendimento. Com este objetivo, estudou-se a sangria por puntura 
em comparação ao sistema convencional, ambos no cultivaf RRIM 600, nas condições do Planalto Paulista. os tratamentos da SPP constituiram-se de combinações de diferentes comprimentos de faixa $(70$ e $100 \mathrm{~cm})$, nümero de punturas $(6 \mathrm{P}$ e $12 \mathrm{P})$ e concentrações de ethephon (ET $2,5 \%$ e ET $5 \%$ ), sendo todos na frequência d/2 6d/7. Em relação a estes tratamentos, observouse que a concentração do estimulante é o mais importante fator determinante da produção, sendo que ethephon 5\% possibili tou maiores incrementos, notadamente em faixas de $70 \mathrm{~cm}$, enquanto que as faixas de $100 \mathrm{~cm}$ foram prejudicadas pelas perdas por escorrimento de lätex para fora da canaleta. Este problema motivou a redução no desempenho da mão-de-obra. Com faixas de $70 \mathrm{~cm}$ e ethephon $5 \%$, não houve diferença estatística entre 6P e I2P em relação a produção, mas nesse caso, o menor nümero de punturas foi mais interessante do ponto de vista operacional, além de reduzir os riscos de danos à casca. A produção na quarta semana após a estimulação não foi com pensadora, o que sugere o uso da periodicidade $3 \mathrm{~s} / 43 \mathrm{~s} / 5$, v sando melhor rendimento por planta/sangria e melhor aproveita mento do seringueiro. A lesão vertical com exposição do lenho foi o mais sério problema observado nos painēis explorados através da SPP, enquanto que o espocamento de casca foi um outro problema registrado, mas minimizado quando utilizou-se menor nü mero de punturas e procedeu-se abertura de faixas suficientemente profundas. A produção do melhor tratamento na SPP $(6 P /(70 \times 1)$.ET $5 \%)$ foi cerca de $29 \%$ superior à sangria conven- 
cional, embora não tenha se mostrado estatisticamente diferen te. Verificou-se que os tratamentos com SPP não mostraram di ferenças significativas no incremento do perimetro do tronco em relação a sangria convencional, com excessão do tratamento citado anteriormente. Em razão dos aspectos apresentados, ob serva-se que a SPP, embora seja uma alternativa à exploração na fase precoce, não constitui uma solução irrestrita; sugere-se a investigação de novos métodos de sangria que possibilitem a resolução dos problemas referidos. 
PUNCTURE TAPPING OF THE CULTIVAR RRIM 600 IN THE SÃO PAULO STATE

Author: ADONIAS DE CASTRO VIRGENS FILHO

Adviser: Prof. PAULO ROBERTO DE CAMARGO E CASTRO

\section{SUMMARY}

The period from planting to opening for tapping the rubber tree (Hevea sp.) lasts from 5 to 7 years, can be in some cases discouraging for the free enterprise, because the absolute success of the investiment demands an exploitation wi thout interfering to its growth. The tapping system adopted in the São Paulo State and in the majority of rubber tree planting centers is $(1 / 2 \mathrm{~s} d / 26 \mathrm{~d} / 7)$ which requires skilled labour, seldom available in the amounts and quality desired. These two aspects of the problem force the beginning of the work earlier using less skilled labour and aiming a higher productivity. Therefore a study was carried out camparing puncture with conventional tapping, in the são Paulo State conditions. The treatment of the puncture tapping consisted of different combinations of the lenght of grooves $(70$ and $100 \mathrm{~cm})$, puncture numbers $(6 \mathrm{P}$ and $12 \mathrm{P})$ and ethephon concentrations (ET $2,5 \%$ and ET $5 \%$ ) all in the $d / 26 \mathrm{~d} / 7$ frequence. It was 
observed that stimulant concentration was the most important factor for yield, being ethephon $5 \%$ enabled greater increases especially in $70 \mathrm{~cm}$ lenght grooves, while the $100 \mathrm{~cm}$ lenght had losses due to leaking of the latex out at the grooves. This problem caused lower labour productivity as well. It was also observed that with $70 \mathrm{~cm}$ lenght grooves and ethephon $5 \%$ there were no significant differences between $6 P$ and $12 P$ as for productivity, but the lower number of punctures presented better results operating and reducing bark damage. Four weeks after stimulation the production was not paying off, which suggests the use of $3 \mathrm{~s} / 4,3 \mathrm{~s} / 5$ periodicidity to obtain a better production per plant per tapping and better use of labour. The most important problem observed on the puncture tapping painels was the vertical lesion with the wood exposition. Another problem was the bark burst, minimized however with groove opening deep enough. The best treatment production on puncture tapping $(6 P(70 \times 1) E T 5 \%)$ was about $29 \%$ highercomparing conventional tapping method, but not a significant difference. The treatments with puncture tapping did not present difference, on trunk circunferences increase comparing to conventional tapping, except the treatment above. The result indicate that the puncture tapping method is an alternative to immature tree exploitation, but it was necessary to study other tapping methods which presented solutions of the problems observed. 


\section{INTRODUCÃO}

A seringueira (Hevea sp.) è a principal fonte produtora de borracha vegetal de superior qualidade. Produtos fabricados a partir da borracha foram registrados desde a divulgação de eventos relacionados com a descoberta e colonização da Amërica (REIS, 1953). Mas somente em 1839, com a descoberta do processo fundamental da vulcanização, a borracha ganhou maior resistência às variações de temperatura, tendo esse fato promovido um grande impulso na fabricação de pneumā ticos. A partir desse acontecimento, ampliou-se o nümero de artigos e usos da borracha e à medida em que se desenvolvia a indūstria automobilística, era incrementada a produção de pneumäticos e câmaras de ar (PHOLHAMUS, 1962).

Essa fase decorreu simultaneamente aos tempos äureos das regiões extrativas da Amazônia, uma vez que a produção não acompanhava a ascendente demanda, elevando-se assim o preço da borracha. Tal situação permaneceu gerando di- 
visas e sustentando riquezas, até que crescentes produções oriundas de seringais cultivados no Sudeste Asiätico, tornaram a borracha extrativa menos competitiva, vindo essa região a assumir o domínio do mercado internacional a partir da segunda década deste século, com reflexos de natureza econômica e social para a Região Amazónica (RE।S, 1953). A partir de 1951, o Brasil passou à condição de importador de borracha vegetal, situação que perdura até os presentes dias.

Com a necessidade de produzir uma matéria prima de mais baixo custo, qualidade padronizada e adicionalmen te, limitar a excessiva dependência da borracha produzida em uma região politicamente insegura, passou-se ao desenvolvimen to da borracha sintética (MENEZES e VASCONCELOS FILHO, 1977), cujo éxito foi alcançado em 1933, pela produção da Buna N e Buna S, polímeros do butadieno com propriedades tecnológicas satisfatōrias (WISNIEWISKI, 1979). Progressos tecnológicos notäveis foram conseguidos após a Segunda Grande Guerra, quan do a produção da borracha sintética teve grande impulso face ao crescimento da indūstria automobilística, ampliação de usos industriais da borracha e principalmente pela abundância e preços relativamente mais baixos do petröleo, sua principal matēria prima. No Brasil, a sua produção teve início em 1962, sendo o crescimento mais acelerado no período de 19701983, quando passou de $75,4 \mathrm{mil}$ toneladas para $220,9 \mathrm{mil}$ tone ladas. Entretanto, com o impacto causado pela crise do petró leo, provocando uma elevação crescente nos preços da borracha 
sintētica a partir de 1973, a borracha vegetal tornou-se mais competitiva, tendo isso refletido na retomada do crescimento da produção brasileira que experimentava decréscimos nos anos de 1973 e 1974 (SOUZA, 1984).

Nos ültimos dez anos, a produção do Brasil aumentou de $19,3 \mathrm{mil}$ toneladas em 1975 para $42 \mathrm{mil}$ toneladas em 1985, enquanto o consumo passou de $57,8 \mathrm{mil}$ toneladas para 102 mil toneladas, nesse mesmo período. Dessa maneira, obteve-se uma ampliação do índice de produção em relação ao consü mo, de 33\% para 41\% (BERNARDES et ali i, 1986). Basicamente, cerca de $75 \%$ da produção é obtida nos seringais nativos, embora nos ültimos anos os seringais de cultivo tenham tido par ticipação crescente, como consequência das políticas adotadas pelo Governo Federal, atravēs do PROBOR - Programa de Incentivo à Produção de Borracha Natural - o qual, em sua terceira fase de execução, tem por objetivo alcançar a auto-sufi ciência na produção e até mesmo, gerar algum excedente para exportação. Para tanto, é previsto a totalização de 388.000 ha de seringais de cultivo até 1994. Até o presente, existem em torno de 173.000 ha financiados pelo PROBOR em todo o Brasil, sendo cerca de $81 \%$ na Região. Norte e o restante da ärea entre as Regiões Nordeste e Centro Sul. Ao abrigo deste programa, estima-se uma ärea plantada em torno de 118.000 ha (SUDHEVEA, 1984).

Entretanto, para a realização de um empreendimento heveicola, considera-se como pouco atrativo o longo pe- 
ríodo existente entre o plantio e o início de exploração da cultura. Essa fase decorre por 5 a 7 anos ou mais, o que representa de 15 a $25 \%$ da vida produtiva das plantas exploradas com a sangria convencional. Esta tëcnica, constitui uma evolução em relação ao sistema empregado nos seringais nativos da Amazónia, porēm, a mesma requer a utilização de mão-de-obra especializada, que nem sempre encontra-se disponível em qual dade e quantidade suficientes. Por outro lado, a sangria con vencional usualmente resulta em baixas taxas de crescimento, quando plantas pouco desenvolvidas são sangradas, decrescendo a produção e o vigor anos mais tarde (DIJKMAN, 1951). Na Malásia, as plantas são consideradas aptas à sangria quando apre sentam $50 \mathrm{~cm}$ de perímetro do tronco à altura de $150 \mathrm{~cm}$ do solo (ABRAHAM, 1980a) e na Costa do Marfim à altura de $100 \mathrm{~cm}$ do Solo (VERNOU e TONNELIER, 1985). No Planalto Paulista, tam bēm è recomendado a exploração de plantas a partir de 50 cm de perímetro à $100 \mathrm{~cm}$ do solo, o que demanda um prolongado pe ríodo sob condições de imaturidade econōmica.

Uma ligeira redução dessa fase é obtida atravẻs da exploração de plantas com $45 \mathrm{~cm}$ de perímetro do tronco à altura de $130 \mathrm{~cm}$ da união enxerto/porta-enxerto, sendo isto seguido de razoáveis taxas de crescimento e satisfatö rias produções, sobretudo quando emorega-se adequado manejo. Esta alternativa ë adotada como rotina nos centros heveicolas sujeitos aos efeitos danosos do Microcyclus ulei P. Henn., onde as plantas têm a fase de imaturidade mais dura- 
doura, notadamente quando hä descaso nos tratos culturais. Avan ços têm sido conseguidos pelo uso de melhores tëcnicas de pro dução de mudas, seleção de clones com crescimento vigoroso, adubações mais frequentes e präticas agronômicas avançadas (NG et alii, 1972). A partir dos estudos de TuPY (1973a), pas sou-se à investigação da sangria por puntura, a qual possibilita a exploração na fase precoce, com perspectivas de bom crescimento da planta. Adicionalmente, pode-se fazer uso de mão-de-obra pouco experimentada e com maior rendimento.

Este trabalho tem por objetivo, investigar os aspectos relacionados com a sangria por puntura, notadamente no que concerne a sua utilização no cultivar RRIM 600 no Planalto Paulista, visando o aprimoramento deste sistema para explo ração precoce da seringueira. 


\section{REVISÃO DE LITERATURA}

o primeiro método de extração do lätex da seringueira (Hevea sp.) foi desenvolvido nos seringais nativos da Amazônia, sendo o mesmo denominado de sangria em corte ama zônico ou em espinha de peixe. O corte era realizado em forma de riscos descontínuos que se sucediam à uma distância de 2 a 5 centimetros, ficando uma faixa de casca intacta. As in cisões eram profundas, atingindo o lenho, e a planta muitas ve zes reagia com a apresentação de cicatrizes ou inchaços nos locais atingidos. Em poucos anos, a região explorada tornava se danificada, de maneira que as plantas eram eliminadas, ou sangradas somente anos mais tarde (DIJKMAN, 1951 ).

Com o início do cultivo da seringueira no Sudeste Asiātico, um novo método de sangria foi desenvolvidopor H.N. Ridley no Singapore Botanic Garden, sendo que este diferia dos sistemas de cortes atuais, pois, acreditava-se que cortes curtos poderiam ser utilizados e as incisões deveriam 
ser pouco profundas. Sua grande evolução baseou-se na importância atribuída às características específicas da casca, uma vez que ${ }^{k}$ passava- a possibilitar plena regeneração dos tecidos, a partir da camada geratriz do câmbio (DIJKMAN, 1951). Es tudos adicionais de carāter anatômico e fisiolōgico foram rea lizados, trazendo novas contribuições ao método de Ridley que constitui o princípio básico do atual sistema convencional de sangria. Por este novo sistema, o corte é realizado usualmente em meia espiral do tronco, através da remoção de finas fatias de casca, com profundidade que se aproxime de atē l mm ou 1,5 mm do câmbio e inclinação em torno de 33 ? com a horizontal, dirigindo-se do alto à esquerda para a parte inferior à direita (ABRAHAM, 1980a). Entretanto, dois problemas bàsi cos estimulam a adoção de alterações nesta prätica de sangria: (a) a necessidade de mão-de-obra especializada; (b) o prolongado período de manutenção da cultura em condições de imaturi dade econômica. Face a esses inconvenientes, abriram-se pers pectivas à investigação de um sistema alternativo, voltado a utilização de mão-de-obra menos laboriosa e com possibilida des de antecipação do retorno econômico da cultura.

Com a descoberta do ethephon (äcido 2 -cloroetil - fosfónicol como estimulante da produção de látex e seu postẹ rior uso associado a sangria por puntura (SPP), estabeleceu-se nova fase de estudos, objetivando a resolução dos problemas mencionados. Com este propósito, inümeros trabalhos têm reportado resultados interessantes pelo uso deste método de san gria. 
A sangria por puntura foi registrada inicialmente por Wright em 1906, mas, race aos danos provocados na casca e devido a baixa resposta na produção, teve seu uso desativado (RRII, 1980; HASHIM, 1980). LUSTINEC et alii (1965), estudaram a região de fluxo do lätex, atravēs da realização de punturas, visando determinar a ärea de drenagem da sangria em meia espiral. Anos mais tarde, trabalhos desenvolvidos por TUPY (1973a), tornaram evidentes as possibilidades da puntura associada ao ethephon. A sangria por puntura, contrariamente à sangria convencional, não elimina os tecidos da casca limitando a circulação da seiva elaborada que favorece a nutrição orgânica ạo nível dos vasos laticíferos. A sua técnica consiste na realização de punturas obliquas em faixas verticais de casca raspada e estimulada, utilizando-se um instrumento pro vido de uma agulha achatada na extremidade (TUPY, 1973a).

\subsection{Sangria por puntura e o uso de estimulantes}

Na sangria convencional o uso de estimulantes

químicos ë recomendado como tēcnica para reduzir os custos de mão-de-obra e consumo de casca, problemas estes que resultam da sangria intensiva (BOATMAN, 1970). Na sangria por puntura o uso de estimulantes é imprescindível, pois, as produções são totalmente dependentes da estimulação. 
A aplicação de estimulantes tem relação com o retardamento na cessação do fluxo de lätex, que usualmente ocor re apōs vārias horas da sangria. A formação do coägulo por partículas de borracha nos vasos próximos a região de corte, limita fluxos adicionais. Esta resistência ao fluxo próxima a zona de sangria é o periodo de obstrução (GOMES, 1979).

os estimulantes anteriores ao ethephon apresentam como fato em comum, o estímulo à produção de etileno endógeno ao passo que o ethephon libera etileno por hidrólise no floema. Por sua vez, o etileno é envolvido no retarda mento à obstrução dos vasos laticíferos, prolongando o fluxo de látex. Para tanto, ele conduz ao aumento na estabilidade da membrana dos lutóides e acelera a ação da invertase no desdobramento da molécula de sacarose, carboidrato que desempenha função importante na biossintese da borracha.

TUPY (1973b), investigou a atividade da invertase, e observou que a mesma tem papel limitante no desencadea mento do catabolismo glucídico, sendo muito dependente do pH. A estimulação, conduzindo a elevação do pH, induz a invertase a uma maior atividade, resultando em maior produção de açü cares e incremento na biossintese da borracha. Estudosexperlmentais dãoconta de uma elevação do pH pelo uso de estimulação, sendo lsso acompanhado do aumento na produção de látex.

No sistema convencional de sangria, ethephon, 2,4-D ou 2,4,5-T, apesar de estimularem o fluxo dé lätex, pro movem crescimento desigual na renovação de casca (BUTTERY e 
BOATMAN, 1967). ABRAHAM et ali $\mathrm{i}(1968,1971)$, reportaram que a maioria dos testes com estimulantes induzem desorganizada proliferação celular oriunda da atividade meristemätica, causando produção de casca mais espessa. Os efeitos de ethephon em relação a esse problema, são menores quando comparados com o $2,4-0$ e o $2,4,5-T$.

ABRAHAM e ANTHONY (1981), estudando concentrações de ethephon na sangria por puntura, encontraram incrementos de $50 \%$ na produção dos cultivares RRIM 703 e GT I, pelo uso de ethephon $5 \%$ em relação a $2,5 \%$. RAMACHANDRAM e LEE (1979), obtiveram produções superiores com ethephon $2,5 \%$ em relação a 1,25\% nos cultivares RRIM 600 e GT I, independente do nümero de punturas $(5$ ou 10$)$, sendo que a maior concentração, proporcionou maior incremento no segundo ciclo do painel. ABRAHAM et alii (1979), registraram produções superiores com'RRIM 600', ou ligeiramente comparāveis com 'GT I' e 'RRIM 600' pelo uso de ethephon $2,5 \%$ em relação ao controle não estimula do $1 / 2 \mathrm{~s} d / 2$. LEONG et ali $(1977)$, obtiveram maior incremento de produção no'RRIM $600^{\prime}$ com ethephon $3,3 \%$ na frequên cia d/3, quando comparado a $3 / 4 \mathrm{~S}$ não estimulado, nesta mesma frequênciá. L.T. Thin citado por HASHIM et alii (1979), encontrou produção $20 \%$ superior pelo uso de ethephon $3,3 \%$ em re lação a $2,5 \%$, ambos na SPP. Em geral, maiores concentrações tendem a melhores respostas na produção. ABRAHAM e ANTHONY (1981), referindo-se a baixa produção nos primeiros meses de uso da SPP, sugeriram a utilização de ethephon $10 \%$ nos pri- 
meiros quatro meses, seguindo-se ethephon $3,3 \%$ nos meses subsequentes. SIVAKUMARAN e GOMEZ (1980), sugeriram o uso da concentração em função da idade da planta, sendo $2,5 \%$ para plantas jovens, $5 \%$ para plantas adultas e $3,3 \%$ para plantas com idade intermediäria.

GENER et alii (1977), computaram um gasto em torno de $750 \mathrm{mg}$ de etheption a $5 \%$ em faixas verticais de $50 \mathrm{~cm}$, com produção aceitẩvel. LEONG et alii (1977), referiram-se ao nivel proposto por Gener et alii como superior ao necessärio. Segundo os mesmos, $554 \mathrm{mg}$ de etheption a $3,3 \%$ por faixavertical de $100 \mathrm{~cm}$ era um nivel adequado, sem efeito comprometedor ao crescimento, produção, teor de sacarose e conteüdo de borracha seca. Aplicação de estimulante em maior quantidade foi reportada por LEONG e TAN (1977), sendo que a mesmacorrespondeu a uma mêdia de 1,38 g por faixa e por aplicação. SIVAKUMARAN e GOMEZ (1980), computaram um consumo variável de 1,5 a $2,0 \mathrm{~g}$ de ethephon a $2,5 \%, 3,3 \%$ e $5 \%$, respectivamente para plantas jovens, em idade intermediăria e adultas, enquanto MORAES (1985), sugere o consumo de 2,0 g por planta e por aplicação de ethephon $5 \%$ em faixas de $100 \mathrm{~cm}$.

RAMACHANDRAN e LEE (1272), encontraram respostas na sangria por puntura a concentração do estimulante, seguindo-se do nümero de punturas por sangria, ou seja, ethephon $2,5 \%$ com 10 e 5 punturas, respectivamente, foram supe- 
riores a ethephon 1,25\% com 10 punturas. HASHIM (1980), reportou decréscimos na produção por efeito da baixa concentra ção de ethephon, ao evoluir de 5 para 10 e 15 punturas por fa xa, enquanto WAIDYANATHA e ANGAMMANA (1981), encontraram correlação positiva entre o aumento no nümero de punturas para doses de $0,5,1,0$ e $2,0 \mathrm{~g}$ de ethephon $5 \%$, em faixa de $100 \mathrm{~cm}$, com 5, 10 e 15 punturas, respectivamente, resultado este também encontrado por SARAMANAYAKE (1985). Com referência a efe tividade do ethephon na SPP, vārios autores são unānimes em afirmar que o tempo decorrido de resposta a estimulação não ultrapassa a terceira semana (PRIMOT et alii, 1978; RAMACHANDRAN e LEE, 1979; L.T. Thin citado por ABRAHAM e ANTHONY, 1981; MORAES, 1984 e 1985). Apōs a estimulação, respostas são mais elevadas durante as duas semanas de sangria, diminuindo nas duas seguintes; no segundo estádio, a produção declina, ficando abaixo da sangria convencional, tornando-se an ti-econômica na quarta semana (ABRAHAM e ANTHONY, 1981; SARAMANAYAKE, 1985). Cerca de 50\% da produção pode ser obtida nos primeiros 8 a 10 dias, atingindo-se um total de $90 \%$ da produção mensal até os 22 dias (Ravoof citado por ABRAHAM e ANTHONY, 1981). Bahia, citado por GOMES e VIRGENS. FILHO (1984) usando o cultivar F× 2261 com ethephon 5\%, encontrou superioridade para os tratamentos com sangria até a terceira semana apös a estimulação $(d / 115 d / 30 ; d / 16 d / 12 ; d / 215 d / 30)$, sendo estes, estatisticamente superiores à sangria em dias alternados por todo o mês $(d / 230 d / 30)$. Alëm dos trabalhos relacionados com a 
SPP na frequência d/2 (MORAES, 1984; LUCKMAN, 1984; SOARES, 1985), existem proveitosos resultados em d/3 (SIVAKUMARAN e GOMEZ, 1980; SARAMANAYAKE, 1984), d/4 (RAMACHANDRAN e LEE, 1979) e d/3 d/4 (PRIMOT et alii, 1978; SIVAKUMARAN e GOMEZ, 1980). WAIDYANATHA e ANGAMMANA (1981), observaram que o uso de frequências entre d/2 e d/6 na SPP não afetou significativamente a produção em g/planta/sangria, mas, melhor.resultado em kg/ha/ano foi obtido na frequência d/3.

\subsection{Aspectos relacionados com a Área de drenagem}

0 volume de látex que escoa na região de sangria é proporcional a sua ārea de drenagem. Na sangria por puntura, a exploração tem sido realizada através de raspagem e estimulação da casca, formando faixas verticais com comprimentos que variam de 20 a $120 \mathrm{~cm}$ e largura de la $2 \mathrm{~cm}$. A extração do lätex è feita mediante a realização de punturas que variam em nūmero de 2 a 15. A ärea de drenagem total do lätex corresponde a soma das äreas de drena gem de cada puntura e da sobreposição dessas áreas em função do seu formato. Como os laticíferos estão orientados no sentido ascendente da esquerda para a direita formando um ângulo em relação ao eixo do tronco, a região atingida por cada furo corresponde a um dreno de formato elíptico ascendente, ficando o eixo maior no sentido longitudinal do caule; ligeiramen 
te inclinado para a direita. Um nümero reduzido de furos, limita a produção pela não exploração da àrea de drenagem tota1. Por outro lado, para se evitar a sobreposição das àreas de drenagem correspondentes a cada puntura e minimizar as rea ções da casca às punturas, o nümero de furós não deve ser excessivo em relação ao comprimento de faixa.

\subsubsection{Comprimentos de faixa}

Muitos trabalhos reportam comprimentos de fai$x$ a entre 20 e $100 \mathrm{~cm}$, com resultados mais favoräveis concentrados entre 70 e $100 \mathrm{~cm}$ (HASHIM, 1980). Faixas inferiores a $50 \mathrm{~cm}$ resultam em produções menores. Estudos comparativos têm demonstrado a superioridade de faixas com $72 \mathrm{~cm}$ sobre $50 \mathrm{~cm}$ (ABRAHAM e ANTHONY, 1981), $80 \mathrm{~cm}$ sobre $40 \mathrm{~cm}$ e $20 \mathrm{~cm}$ (LEONG et alii, 1977), e bons resultados em faixas de 75 a $90 \mathrm{~cm}$ (RA MACHANDRAN e LEE, 1979), e $100 \mathrm{~cm}$ (SARAMANAYAKE, 1985). SIVAKUMARAN e GOMEZ (1980), sugerem comprimentos em torno de 80 a $88 \mathrm{~cm}$ para exploração de painéis alto e baixo, enquanto 50 a $72 \mathrm{~cm}$ seria ideal para painēis alto, médio e baixo. Bahia, citado por GOMES e VIRGENS FILHO (1984), utilizou faixas de $50 \mathrm{~cm}$ com o cultivar Fx 2261 e obteve produções inferiores ao controle $1 / 2 \mathrm{~S} d / 2$. Por sua vez, WAIDYANATHA (1985), utilizando o mesmo cultivar e faixas de $100 \mathrm{~cm}$, obteve um significativo aumento de produção em relação ao mesmo sistema. 0 maior escorrimento do látex para fora da faixa dificulta o 
uso do comprimento de $100 \mathrm{~cm}$, sobretudo quando a casca é menos espessa, elou não se procede a remoção semanal do cernam bi fita. HASHIM et ali (1979), observaram que cerca de até $30 \%$ da produção de 1 ätex pode ser nerdida por escorrimento na SPP se o mesmo não for devidamente conduzido até a tigela. Es te problema pode ser atenuado pela não realização da sangria em plantas com a casca do caule molhada e utilização de faixas com adequada profundidade (MORAES, 1985). Faixas de $50 \mathrm{~cm}$ são mais präticas para a sangria e proporcionam mínimo escorrimento, mas, são baixas as produções. Baseando-se na produção e aspectos operacionais, considera-se mais adequado o comprimento de $80 \mathrm{~cm}$ (ABRAHAM e ANTHONY, 1981).

\section{2 .2 . Largura de faixa}

A largura de faixa habitualmente usada tem sido de $1 \mathrm{~cm}$ com sulcos de 2 a $4 \mathrm{~mm}$ parafacilitar o fluxo de lätex; a largura de $2 \mathrm{~cm}$ è tambëm utilizada, mas completa uma volta em torno do tronco em um período mais curto e pode requerer uso adicional de estimulante (HASHIM, 1980). Hashim, ci.tado por RAMACHANDRAN e LEE (1979), computou um gasto de $1,1 \mathrm{~g}$ e $1,84 \mathrm{~g}$ de ethephon por ano na aplicação em faixa de $100 \mathrm{~cm} \mathrm{com} 1 \mathrm{~cm}$ e $2 \mathrm{~cm}$ de largura, respectivamente. Por sua vez, estes mesmos autores não observaram diferença no consumo de ethephon pelo uso de faixas com estas mesmas largu ras. Com referência a 2 cm, RAMACHANDRAN e LEE (1979), ass i 
nalaram produção $16 \%$ superior a $1 \mathrm{~cm}$, enquanto SIVAKUMARAN e GOMEZ (1980), atestaram um incremento de $10 \%$. Em ambos os tra balhos, concluiu-se pela limitação no uso de faixas mais largas em razão do maior consumo de casca, uma vez que nova fai$x a$ é mensalmente aberta paralelamente à anterior e estimulada.

\subsubsection{Altura de localização das faixas}

A altura de localização das faixas verticais tambēm tem relação com a àrea de drenagem. Pinheiro, citado por SOARES (1985), reportou sobre a provável influência do por ta-enxerto ao observar que faixas com a parte inferior local zada à altura de $90 \mathrm{~cm}$ do tronco, redundam em maior produção que aquelas localizadas a $40 \mathrm{~cm}$. RAMACHANDRAN e LEE (1979), obti veram produção $30 \%$ superior em faixas localizadas entre llo e $200 \mathrm{~cm}$ acima do ponto de união enxerto/porta-enxerto, quando comparadas a faixas localizadas entre 20 e $100 \mathrm{~cm}$. Presume-se a existência de uma melhor àrea de drenagem na exploração de faixas com a parte inferior localizada em pontos mais distantes do porta-enxerto. Um outro aspecto a considerar é o provável efeito "ilha de casca" (a produção diminui a medida que a sangria aproxima-se da casca em renovação) que pode ocorrer na subsequente exploração com a sangria convencional. 


\subsubsection{Nümero de furos}

os resultados de värios trabalhos não definem um ponto em comum em relação a melhor distância entre punturas. LEONG e TAN (1977), observaram que o nümero ötimo de punturas ficou entre 4 a 6 para comprimentos de faixa entre 60 e $80 \mathrm{~cm}$. HASHIM (1980), definiu um nümero de 5 a 7 punturas para um comprimento ótimo de faixa $(70$ a $80 \mathrm{~cm})$. ABRAHAM e ANTHONY (1981), obtiveram resultados favoráveis com 6 punturas em faixas de 50 a $72 \mathrm{~cm}$, respectivamente, enquanto RAMACHANDRAN e LEE (1979), exploraram satisfatoriamente faixas de $90 \mathrm{~cm} \operatorname{com} 7$ e 10 punturas, respectivamente. Em faixas de $100 \mathrm{~cm}$, PRIMOT et alii (1978), concluíram pelo nümero de 4 a 5 punturas para se obter maior produção. Por sua vez WAIDYANATHA e ANGAMMANA (1981) e SARAMANAYAKE (1985), investigaram variações de 5,10 e 15 punturas por faixa de $100 \mathrm{~cm}$, obtendo maiores produções a medida em que aumentavam o nümero de punturas, contrariando o resultado obtido por HASHIM et alii (1979), que obtiveram produções mais altas com 5 punturas, quan do comparado com 3,10 e 15 punturas, respectivamente, em faixas de $100 \mathrm{~cm}$, concluindo assim, pela distância de $20 \mathrm{~cm}$ en tre punturas para melhor exploraçäo da ärea de drenagem. MORAES (1984), admite esta distância como o ponto de equilíbrio no qual se obtēm melhor ampliação da àrea de drenagem com o mínimo de punturas. 


\subsubsection{Profundidade de perfuração}

Em estudos realizados com estiletes decomprimentos de 6,8 e $9 \mathrm{~mm}$, respectivamente utilizados em casca com 9,5 mm de espessura mëdia, verificou-se que a produção era maior com o incremento no comprimento do estilete, indicando que os laticifferos mais próximos do câmbio eram mais produtivos (IRCA, 1980). ABRAHAM e ANTHONY (1981), obtiveram produções su periores com estilete de $10 \mathrm{~mm}$ de comprimento em relação a 4 mm; entretanto, admitiram que nos primeiros meses da spp devese usar $6 \mathrm{~mm}$ e nos meses subsequentes, estiletes de $8 \mathrm{~mm}$. A profundidade de incisão é limitada pela espessura decasca. Em plantas com casca pouco espessa, evita-se maior comprimento do estilete para que não haja deslocamento de casca. Sob condições de casca mais espessa, o comprimento do estilete deve ser o suficiente para atingir os vasos laticiferos mais produti vos. WAIDYANATHA e ANGAMmANA (1981) e SARAMANAYAKE (1985) ao estudarem diferentes espessuras de estiletes observaram que variações entre 1,0, 1,5 e 2,0 mm, näo produziram resposta di ferencial na produção. Neste caso, conclui-se pela superioridade da espessura de $1 \mathrm{~mm}$, devido a maior facilidade para a penetração da agulha e abertura de menor orificio na casca.

2.3. REAgÕEs anATOMMICAS A SPP

Entre os mais sërios problemas decorrentes da 
adoção da SPP, encontram-se as reações da casca devido as punturas, sendo o espocamento de casca o de maior importância. Alguns cultivares apresentam maior suscetibilidade do que outros (SIVAKUMARAN e GOMEZ, 1981), e, em alguns casos, is so é restrito ao período em que a planta apresenta-se com perímetro do tronco inferior a $40 \mathrm{~cm}$, tal como observado por SOARES (1985), em relação ao cultivar Fx 3899. A sensibili dade deste cultivar também foi constatada por MORAES (1984). Bahia, citado por GOMES e VIRGENS FILHO (1984), encontrou rea ções da casca para o' $F \times 3899^{\prime}$, 'Fx 3864' e 'Fx 2804', enquanto RAMACHANDRAN e LEE (1979), observaram no 'PR 107', HAS HIM et alii (1979) no 'PR 107' e 'PR 255' e ABRAHAM e ANTHONY no 'RRIM 703' e 'GTI'. Em outros cultivares como 'RRIM 600', 'Fx2261'e'IAN 717', estas reações, embora constatadas, têm menores efeitos (HASHIM et alii, 1979; GOMES e VIRGENS FILHO, 1984; SOARES, 1985). I sto demonstra a necessidade de estudos sobre a resposta dos diferentes cultivares à SPP. E provável que as células do càmbio, em cultivares mais sujeitos a ferimentos, sejam mais reativas e sensiveis, podendo ferimentos na casca serem comuns tanto na sangria por puntura como na sangria convencional. Neste caso, sugere-se retardar o uso desses cultivares até o estädio em que a casca esteja mais espes sa (SIVAKUMARAN e GOMEZ, 1981).

2.3.1. Espocamento de casca

São lesões que ocorrem de preferência nos pri- 
meiros quatro meses de sangria por puntura, pois com a retirada da agulha, há puxamento da casca formando úm espaço interno para onde escoa o lätex que a seguir, coagula-se entre a casca e o lenho (ABRAHAM e ANTHONY, 1981; MORAES, 1981). Plantas de menor perímetro do caule e consequentemente de cas camais flexivel por ser mais fina, têm espocamento mais fre quente. Apōs remoção da casca danificada e do coägulo de bor racha formado entre a casca e o lenho, a cicatrização da região atingida se procede por um período inferior a 12 meses, mesmo sem aplicação de fungicida (MORAES, 1985). Gasparotto e Trindade, citados por MORAES (1985), recomendaram por prevenção o tratamento indicado para ferimentos no caule. Esse critērio é de suma importância, notadanente em regiōes favorāveis à manifestação de patōgenos, onde as enfermidades observadas no painel de ex ploração, causam sérias consequências em plantas submetidas à sangria con. vencional. MORAES (1981), sugeriu a realização de punturas oblíquas para contornar o problema do espocamento. Anos mais tarde, concluiu-se pelaine ficiência de tal medida, pois mesmo com a realização de punturas obliquás, houve espocamento de casca em ärvores com raspagem superficial deixando ainda uma camada de casca dura. Por outro lado, não foi observado espocamento emärvores cujas ca naletas foram aprofundadas suficientemente (MORAES, 1985).

\subsubsection{Inchaço}

Trata-se da formação de nodosidades no tronco 
pelo crescimento irregular de tecido lenhoso nos locais das punturas. HAMZAH e GOMEZ (1981), verificaram esse problema com o cultivar RRIM 600. SOARES e PINHEIRO (1984), registraram uma incidência em torno de $3,3 \%$ das plantas sem distin ção entre os cultivares $\mid A N 717$ e Fx 3899 e idade de exploração. MORAES $(1984,1985)$, trabalhando com os cultivares Fx 3899, FX 3810, IAN 717, IAN 873, PFB 5 e FX3864, encontrou esse tipo de reação em apenas $2,5 \%$ das plantas do 'Fx386 ', embora na maioria dos casos, as punturas atingissem o lenho. 0 inchaço pode possibilitar o escorrimento do látex pa ra fora da faixa vertical, em decorrência da deformação causada no tronco. Todavia, a sua ocorrência não impede a subsequente exploração das plantas (SOARES e PINHEIRO, 1984).

\subsubsection{Fendilhamento de casca}

São fendilhamentos longitudinais da casca ao longo da primeira canaleta, sem clara percepção a olho nū e às vezes acompanhados da exsudação de lätex. Este problema foi observado por MORAES (1985), no cultivar IAN 873 , sendo atribuído à torção e flexão do tronco sob copa pesada, quando submetida a acão de vento forte. A ocorrência foi restrita a primeira canaleta. A existência de canaleta vertical, devido a exploração pela SPP, possibilita menor grau de resistência à casca, tornando-a mais suscetivel ao fendilhamento. 


\subsection{TEOR de sacarose}

Através do uso de técnicas com radioisōtopos observa-se que carboidratos, como a sacarose, são fornecidos aos vasos laticiferos, onde têm importante papel na biossíntese da borracha. Fatores que incrementam o catabolismo da sacarose, como a ativação da invertase pela elevação do pH, estimulam o fluxo de látex. Este evento é beneficiado com o uso de estimulantes e influenciado por outros fatores como caracteristicas clonais e sistemas de sangria. A sangria convencional afeta a translocação de sacarose a maiores distâncias devido a remoção do floema secundário, sendo que o nível de sacarose decresce à medida que incrementa a superfície de cor te sobre a casca (TUPY, 1984). Um dos argumentos favoráveis sobre a sangria por puntura refere-se ao melhor suprimento de sacarose na àrea de drenagem do látex, pois a SPP não elimina a casca, perturbando a circulação da seiva elaborada e por conseguinte, favorece a nutrição glucídica dos vasos laticífe ros (TUPY, 1973a). Embora não se exclua a possibilidade de que a SPP ao atingir os anéis mais pröximos do câmbio tenha influência sobre as propriedades do látex, admite-se que esta técnica permite uma melhor circulação dos assimilados pela não eliminação do floema funcional (IRCA, 1978).

São muitos os trabalhos que reportam a existên cia de maior teor de sacarose no látex de plantas submetidas a SPP quando comparadas àquelas sangradas em espiral (GENER et 
alii, 1977; LEONG e TAN, 1977; LEONG et alii , 1977; HASHIM et ali i, 1979; THIM et alii, 1979; IRCA, 1980; WAIDYANATHA e ANGAMMANA, 1981). LEONG e TAN (1977), observaram uma redução no teor de sacarose do lätex ao passarem para exploração da SPP em casca regenerada. Por outro lado, não foram registra das diferenças significativas entre comprimentos distintos de faixa $(40$ e $80 \mathrm{~cm})$, nümero de punturas $(2,4,6,8,10$ e 16 punturas) e nümero de estimulações por ano $(2,4,6$ e 12 es timulações), enquanto que a frequência de sangria em d/2, levou a um ligeiro decréscimo em relação a d/3 (LEONG e TAN, 1977). Em contraste, WAIDYANATHA e ANGAMMANA (1981), verificaram menor teor de sacarose pelo uso de faixas de $100 \quad \mathrm{~cm}$ em comparação a $50 \mathrm{~cm}$. HASHIM et ali (1979), reportaram que o teor de sacarose no lätex, decresce na seguinte ordem dos sistemas de sangria: SPP, Micr-X e sangria em espiral. VERNOU e TONNELIER (1985), observaram menor teor de sacarose em plantas do 'RRIM 600' exploradas precocemente por puntura, em comparação com a meia espiral com abertura à sangria três anos apös. Em relação ao 'GT l', as diferenças não foram significä tivas.

\subsection{Doencas do Painel}

Entre as doenças de importância relacionadas com o painel de sangria, deve-se mencionar o "secamento de 
painel", o qual ẻ uma doença motivada pela maiòr intensidade de sangria. Os estudos em torno do assunto têm demonstrado que os primeiros sintomas para sua ocorrência consiste no romprimento dos lutöides e na deficiência de tiols. E pos sível que o balanço entre a síntese de borracha e sua exportạ ção pela sangria, conduza a uma modificação na composição pro teolipídica na membrana dos lutóides e na atividade enzimätica (Sherief e Sethuraj; Cretine Noirot, citados por SYPE, 1984). O desequilíbrio iônico favorece a redução da estabili dade do látex e plantas submetidas a excessiva exploração, têm o potencial osmōtico reduzido; os lutóides são sensíveis a trocas osmóticas, grandes estresses e ação de cätions (PARAJON THY et alii, 1975). Tem sido demonstrado que a deterioração da membrana dos lutóides provoca a ativação de NADH oxidase, produtor de oxigênio tóxico. Por outro lado, a presença dos lutóides é necessāria para a atividade do ATP que tem o auxílio da bomba de prótons, a qual mantém o balanço do pH e íons (citrato, cálcio, maqnésio) no soro citoplasmático. Subsequen temente, o pH e os tiols interviriam na regulação do metaboI ismo, enquanto o oxigênio tóxico e os ions, favoreceriam a coa gulação do làtex (SYPE, 1984).

A coagulação do látex no interior dos vasos, pode naturalmente conduzir a sua morte. Provavelmente, fatores histológicos como seccionamento das paredes dos vasos, ti loses e células pétreas, seguem ao desenvolvimento dos distürbios causados pelos danos aos lutóides, enquanto fatores 
como a necrose dos tecidos e hiperplasia das células em volta, conduzem à morte dos vasos laticíferos (PARAJONTHY et alii 1975).

Segundo SYPE (1984), as características fisiolögicas do látex de plantas que exibem esta doença não säo fundamentalmente diferentes das características de plantas sa dias. Entretanto, TUPY (1984) reportou que a maior incidência de secamento está associada com o baixo nível de sacarose no látex.

Esta doença trata-se de um distürbio fisiolögi co causado por intensiva exploração; sua maior ocorrência ë favorecida pela suscetibilidade do cultivar utilizado, maior frequência de sangria e maior comprimento de corte em plantas submetidas a sangria em espiral (PARAJONTHY, 1980). Por este método de sangria, a frequência de cortes induz mais ao secamento que a aplicação de ethephon. Há registros sobre a sua menor ocorrência em plantas submetidas à sangria por puntura (LEONG et alii, 1977; WAIDYANATHA e ANGAMMANA, 1981). ABRAHAM e ANTHONY (1981), constataram a existência de secamento de painel em 3 plantas num total de 2.980 plantas, durante 18 me ses de SPP. Através da puntura, é raro o secamento em todos os pontos ao longo da faixa; secamento temporário tem sido ob servado, mas a planta continua a produzir nas demais punturas, pröximo do local atingido (HASHIM et alii, 1979).

MORAES (1984), referiu-se ao elevado. Indice de secamento do painel encontrado por Paiva e Gongalves em plantas dos cultivares $F \times$ 
$3899(80 \%)$ e IAN 717 (34\%) em sangria no sistema contencional, enquanto registrou apenas uma incidência inferior a $100 \%$ para - 'Fx 3899' submetido a SPP. Ainda em relação a estes cultivares, SOARES (1985), apôs seis anos de exploração pela SPP, observou a ocorrência de secamento em apenas uma planta do 'FX 3899'.

Outras duas importantes doenças associadas com sangria são o cancro do painel (Phytophthora spp.) e o mofo cinzento (Ceratocystis fimbriata Ell E Halst). No sul da Bahia, onde as condições ambientais favorecem a plena manifesta ção destes patỏgenos, observam-se sērios danos em plantas submetidas à sangria convencional, comprometendo seriamente a renovação de casca (GOMES e VIRGENS FILHO, 1984). Nessa mesma região, o uso da sangria por puntura no cultivar Fx 2261, não possibilitou a ocorrência de Phytophthora sp. no painel, enquanto plantas submetidas à sangria em $1 / 2 \mathrm{~S} d / 2$, tiveram um indice de infecção entre $33 \%$ e $42 \%$ (WAIDYANATHA, 1985). ABRA HAM e ANTHONY (1981) e HASHIM et alii (1979), não observaram a ocorrência de patógenos quando do exame de casca em plantas submetidas à SPP. Na SPP os pequenos orifícios são obstruídos por coägulos de borracha, impossibilitando a penetração de microrganismos apôs a sangria, sendo isto uma vantagem em relação a sangria por cortes, a qual expõe contínuamente a cas ca (MORAES, 1985). Face a esta característica, a sangria por puntura deve ser melhor estudada em regióes onde as doenças de painel constituem um grande problema à exploração da heveicultura. 


\subsection{Efeitos nO CREsCimento e PRODUĞ̃̃O}

A SPP ë quase sempre investigada como potencial para uso em plantas no estádio precoce; por esta razão, o crescimento do tronco è mensurado como um parâmetro indicat vo das possibilidades de uso desta técnica. TONNELIER (1979), obteve boas produções em plantas do 'RRIM 600' iniciadas na SPP com perímetro em torno de 29 a $30 \mathrm{~cm}$, sem contudo observar competição com o crescimento do tronco. ABRAHAM e ANTHONY (1981), verificaram boas respostas de produção em plantas com perímetro do tronco em torno de $36 \mathrm{~cm}$, mas o crescimento obtido foi de 3,4 a 4,2 cm na SPP contra 11,4 a $13,2 \mathrm{~cm}$ na sangria convencional. Bahia, citado por Gomes e VIRrENS fILHO (1984), usou plantas do 'Fx 2261' com perímetro do tronco em torno de 29 a 35 cm e obteve produção inferior à sangria convencional sem prejuizo no incremento do tronco. SOARES (1985), obteve efeito depressivo no crescimento de plantas do 'Fx 3899' iniciadas na SPP com perímetro do tronco a partir de 30-37 cm; em adição, a exploração deste cultivar neste estädio de desenvolvimento, não logrou ganho de produção em relação a plantas exploradas a partir de 38 a $47 \mathrm{~cm}$. Por sua vez, plantas do 'IAN 717' submetidas a SPP na fase mais precoce, possibilitaram melhor produção cumulativa, mas, decrēscimos foram observados a partir do quinto ano de sangria. SARAMANAYAKE (1985), não encontrou diferença significativa em relação ao crescimento do tronco entre o método convencional 
de sangria e a SPP em plantas do 'PB 86' com início de exploração a $30,4 \mathrm{~cm}$, mesmo com a produção nos dois primeiros anos sendo superior na SPP.

RAMACHANDRAN e LEE (1979), admitiram efeito depressivo no crescimento pela exploração de plantas com perí metro inferior a $40 \mathrm{~cm}$, sendo que acima de $48 \mathrm{~cm}$ o crescimento não foi afetado. WENXIAN e JINGUI (1981), definiram $50 \mathrm{~cm}$ de perímetro como limite mínimo para obter melhor produção e crescimento em plantas do'GT $l$ ', quando comparou-se a SPP em relação à sangria convencional; plantas com 30 a 49 cm não lograram, respostas favoráveis. Teoh Cheng Hai citado por RAMACHANDRAN e LEE (1979), observou que plantas com menos de $45 \mathrm{~cm}$ de perímetro, quando submetidas a SPP, tiveram crescimento inferior a plantas não sangradas, sendo essa diferença mais marcante quando se obteve maior produção. Por outro lado, para um menor nível de produção, o crescimento na SPP foi superior à sangria convencional. MORAES (1985), reportou uma produção máxima de 18 aramas por sangria como limite pa ra não haver comprometimento da produção futura em plantas iniciadas à sangria com perímetro a partir de $35 \mathrm{~cm}$.

SIVAKUMARAN e GOMEZ (1981), ao utilizarem plan tas dos cultivares 'RT I', RRIM 600 e PR 107 , observaram que a produção da sangria convencional realizada em casca previamente sangrada na SPP foi comparável e às vezes superior a obtida em plantas dos mesmos cultivares sangrados convencio-nalmente a partir da abertura, sendo isso atribuído ao efeito 
residual do estimulante e maior espessura da casca conservada com bom crescimento. BINGZHONG et alii (1981), verifica ram que a estimulação inibe o crescimento das plantas, näo somente porque mais assimilados são consumidos para a síntese de borracha, mas tambēm porque o ethephon tem efeito regulador na atividade do câmbio, inibindo o crescimento do xilema e estimulando o crescimento radial do floema e dos vasos lat cíferos. Isso induz a formação de uma estrutura anatómica com melhores perspectivas à subsequentes produções. Melhores respostas em casca previamente submetida a SPP, foram tambëm conseguidas por LEONG et alii (1977) com o cultivar RRIM600 , RAMACHANDRAM e LEE (1979) com 'GT I' e 'RRIM 600', IRCA (1980) com 'GTI', 'PB 5/51'e 'PR 107', MORAES (1984) com 'Fx 3810', 'Fx 3899' e 'Fx 3864', Bahia citado por Gomes e VIRGENS FILHO (1984) cOM O 'FX 2261' e SARAMANAYAKE (1985) com o 'RRIC IOI'. Estes resultados indicam que plantas anteriormente submetidas à SPP podem ser posteriormente exploradas pela sangria em espiral, apös regeneração de casca. Entretanto, plantas exploradas precocemente e por um maior período atravēs da sangria por puntura, proporcionam produções inferiores anos mais tarde, mesmo com a sangria convencional (VERNOU E TONNELIER, 1985; SARAMANAYAKE, 1985 e SOARES, 1985).

\subsection{TAMANHo DA tarefa}


aproveitamento do seringueiro atravēs do aumento no nümero de plantas por tarefa. Este aspecto tem sido quantificado em vä rias investigações, concluindo-se pelo maior rendimento da sangria por puntura em relação à sangria convencional. ABRAHAM et alii (1979), computaram um nümero médio de 700 plantas por tarefa na SPP e 500 plantas em l/2S d/2. Adicionalmente, observaram que em terrenos planos gastava-se de 2,4 a 3,8 horas para completar a atividade de sangria através SPP, enquanto em terrenos declivosos, gastava-se de 3,9 a 4,6 horas, indicando que as condições topogräficas têm marcada influência sobre o rendimento do seringueiro, informação esta tambēm registrada por SARAMANAYAKE (1985). Alēm desse aspecto, MORAES (1985), registrou que o rendimento na tarefa tambëm depende do índice de aproveitamento de plantas à sangria e da ancestralidade do cultivar utilizado. Segundo seu trabalho, cultivares com ascendência de Hevea benthamiana têm cernambi fita de maior adesividade, rompendo-se facilmente ao ser puxa do para fora da canaleta, resultando em menor rendimento no trabalho de sangria. Por sua vez, RAMACHANDRAN e LEE (1979), obtiveram um nümero médio de 600 plantas por tarefa na SPP, enquanto em $2 / 3 \mathrm{~S} d / 3$, o nümero ficou entre.480 e 510 plantas. A produção por seringueiro teve $50 \%$ de incremento com o aumento de $25 \%$ de plantas por tarefa na SPP. ABRAHAM e ANTH NY (1981), encontraram um nümero médio de 540 plantas por tarefa na SPP, com registro mínimo de 480 plantas e mäximo de 600 plantas por tarefa. Em terrenos planos com densidade ao re 
dor de 40.0 plantas em sangria por hectare do cultivar laN 873 (H. Brasiliensis), MORAES (1985) registrou um nümero mêdio de 650. plantas por tarefa, enquanto para O 'IAN 717' (H. benthomiona), computou um nủmeromäximo de 480 plantas por tarefa, sendo que o rendimento neste cultivar poderia ser aumentado pela retirada do cernambi fita na vểspera da sangria. Em terrenos com relevo acidentado, a tarefa de sangria poderia ser reduzidaao nível do nümero de plantas utilizadas na sangriaconvencional. TONELLIER et alii (1979), registraram uma mëdia de 400 plantas para a coleta da produção na forma de borracha cơggulada em sa cos de plástico. Com a perspectiva de realização da SPP por três semanas após a estimulação, seguidas por uma semana de repouso, pode-se ampliar o rendimento do seringueiro pela exploração de três a quatro tarefas (ABRAHAM e ANTHONY, 1981, MORAES, (1985). 


\title{
3. MATERIAL E MÉTODOS
}

\author{
3.1. Material
}

\subsubsection{Localização e clima}

o experimento foi instalado na Fazenda Nossa Senhora Aparecida, localizada no municipio de Colina, situado no Planalto, Região Norte do Estado de São Paulo. o local apresenta as seguintes coordenadas geogräficas:

Latitude: $20943^{\prime} 05^{\prime \prime} \mathrm{S}$

Longitude: $48: 32^{\prime} 38^{\prime \prime}$ W. Gr.

Altitude: $588,88 \mathrm{~m}$.

o clima è mesotērmico sofrendo variações pouco bruscas; a temperatura média anual fica em torno de 22 : C, sendo a média das mäximas do mês mais quente de 30 : C e média das mínimas do mês mais frio del2:C. De maneira geral as chu vas ocorrem de outubro a março, com distribuição tropical, sendo 
$83 \%$ nesse período e $17 \%$ no período seco (abril a setembro). Segundo o Atlas Climático e Ecológico do Estado de São Paulo (SETZER, 1966), O clima é caracterizado como do tipo "Ccw" da classificação de kbeppen. No zoneamento agroclimático para a heveicultura no Brasil, esta região está inserida na faixa preferencial, com evapotranspiração real superior a $900 \mathrm{~mm}$, déficit hídrico anual de 0 a $200 \mathrm{~mm}$ e condições térmicas e hí dricas satisfatórias (ORTOLANI et alii, 1983). Dados relativos a precipitação e temperatura, computados no período do ex perimento, na unidade de observação mais pröxima (Bebedouro), são apresentados na tabela l. Essa unidade éstá localizada a uma distância inferior a $35 \mathrm{~km}$ do experimento. Deve-se salientar que este periodo foi caracterizado como atípico, apre sentando um prolongado período seco, causando sérias consequências à agricultura e pecuária na Região Norte do Estado de São Paulo.

Visando estabelecer comparações e analisar resumidamente os decréscimos da produção agrícola no ano de 1985, CAMARGO et alii (1986), utilizaram dados de temperatura média e precipitação pluvial, representativos de vinte locaI idades distribuídas no Estado de São Paulo. Em relação a Região de Colina, tomamos por similaridade nesse trabalho, a localidade mais prōxima, ou seja, Ribeirão Preto, para a qual foram elaborados balanços hídricos correspondentes ao ano de 1963, reconhecidamente um dos anos mais secos do século, e va lores médios (normais), possiblitando-nos comparações com o 
Tabela 1. Dados climáticos registrados na unidade de observa ção mais próxima do local do experimento (Bebedouro, S.P.), no periodo de janeiro/85 a fevereirol 86.

Meses

Precipitação

$(\mathrm{mm})$
$T \max$

. C

27,8

29,5

28,5

28,7

25,7

21, 6

21,7

27,2

29,0

29,9

30,6

30,4

32,0

29,0
$T \min$

?C
Outubro

Novembro

Dezembro

Janeiro/86

Fevereiro
142,9

169,6

338,2

213,0
19,4

20,6

20,2

19,4

17,3

12,7

12,4

16,3

19,3

20,0

20,9

21,0

23,0

19,0

Fonte: Casa da Agricultura da Coordenadoria de Assistência Tëcnica Integrada (CATI, Bebedouro - S.P.) 
ano de 1985. Como observado na figura l, a seca em ambos os anos foi bastante intensa, com um total de $466 \mathrm{~mm}$ de deficiên cia hídrica anual, distribuida de março a dezembro de 1963 , contra $336 \mathrm{~mm}$ de 1985. Estas informações servem para ilustrar a ocorrência de adversidades climáticas no ano de condução deste trabalho, notadamente nos meses de junho a setembro, ocasionando uma periódica redução na produção em seringais mais próximos a localidade de Colina.

\section{1 .2 . Solo}

0 solo é classificado como latossolo vermelho es curo fase arenosa. Sua anälise granulométrica é apresentada na tabela 2 .

As informações registradas nesta anälise configuram boas condições físicas no que diz respeito à composição granulométrica do solo para o cultivo da seringueira. 0 solo é bem drenado, plano, com profundidade efetiva superior a $1,20 \mathrm{~m}$ e de boa aeração.

A anälise química do solo é apresentada na tabela 3. Baseando-se nas recomendações de CAP.DOSO (1985), para adu bação e calagem da cultura da seringueira no Estado de São Paulo, observa-se a necessidade de aplicação de fertilizantes para obtenção de produções mais significativas, o que não foi procedido no experimento, devido ao fato de o manejo adotado ter sido semelhante ao empregado pelo produtor; quanto a apli- 


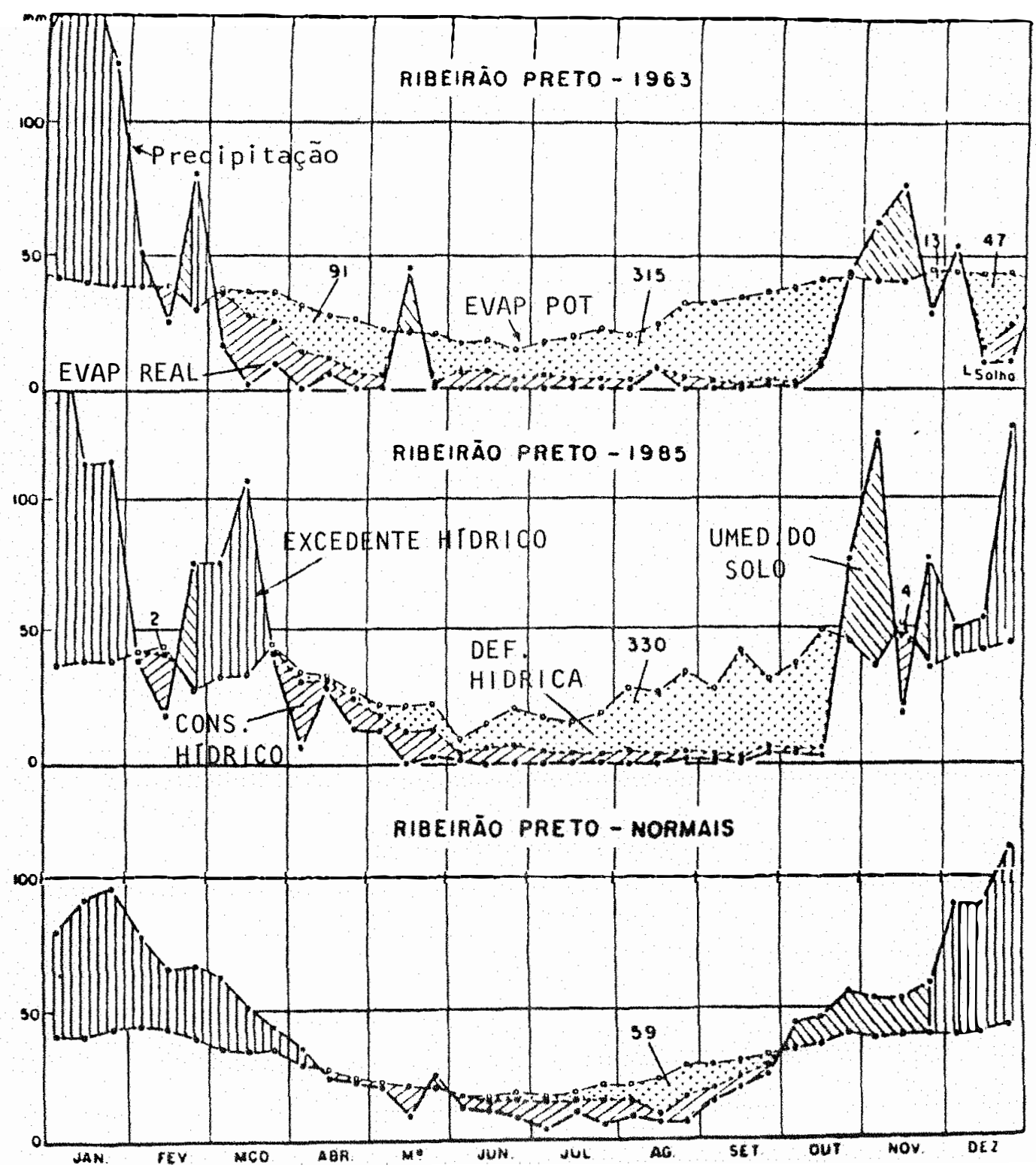

Figura 1. Resultados de balanços hidricos decendiais, referentes aos anos de 1963 e 1985 e médios (normais), para Ribeirão Preto. 
Tabela 2. Análise granulométrica da amostra de solo coletada no local do experimento.

Constituintes granulomētricos al

Areia muito grossa

0,1

Areia grossa

0,5

Areia média

13,8

Areia fina

45,2

Areia muito fina

8,2

Areia

67,8

Silte

9,6

Argila

22,6

al Análise realizada no Laboratório do Departamento de Solos, Geologia e Fertilizantes da Escola Superior de Agricultura "Luiz de Queiroz".

Tabela 3. Anälise química da amostra de solo coletada no local do experimento.

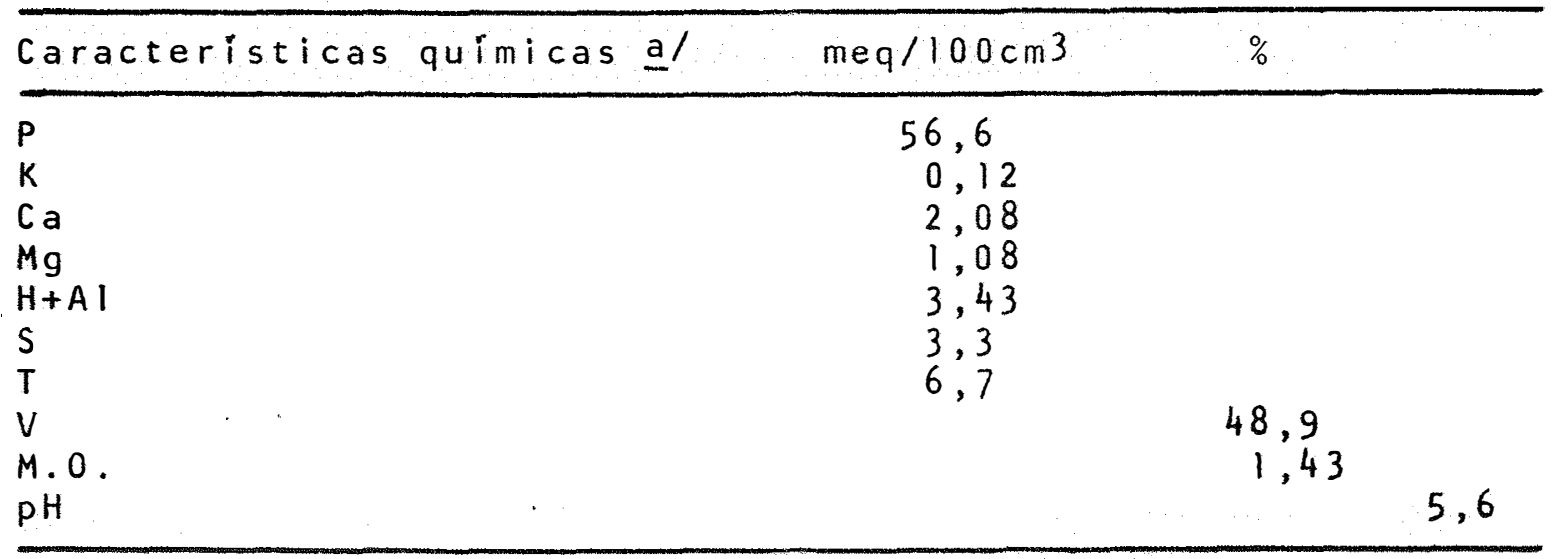

al Anälise realizada no laboratörio do Departamento de Química e Nutrição Mineral de Plantas da Escola Superior de Agricultura "Luiz de Queiroz". 
cação de corretivo de acidez do solo, considera-se dispensável em razão do pH verificado na anălise.

\subsubsection{Material botânico}

Foram utilizados porta-enxertos oriundos de se mentes obtidas através de polinização aberta e coletadas a partir de plantas adultas de pés-francos e de plantas adultas enxertadas, sendo todas com ancestralidade da espécie Hevea brasiliensis Muell. Arg. Na enxertia, utilizaram - se borbulhas coletadas em vergônteas do cultivar RRIM 600 , sen do esse o material de plantio mais empregado na expansão da heveicultura no Planalto de São Paulo.

\subsection{MÉTODOS}

3.2.1. Instalação do plantio

Em 1978 procedeu-se a instalação de um viveiro a pleno solo no espaçamento de $0,70 \mathrm{~m} \times 0,20 \mathrm{~m}$, objetivando a formação de mudas através da técnica de enxertia marrom, segundo o método modificado por Forket (FERWERDA, 1969), 10 a 12 meses após a repicagem das plântulas da sementeira. Após condução, enxertia e decapitação do viveiro, fez-se a seleção das mudas em determinados espaçamentos, passando estas a cons 
tituirem um plantio heveicola no mesmo local, depois da retirada das demais mudas produzidas e eliminação dos porta-enxer tos não aproveitados. Esse processo só foi totalmente concluído por volta de 20 meses apös a instalação do viveiro, quando deu-se a formação de um "stand" menos adensado no local definitivo. As plantas selecionadas passaram a ter espaçamentos variando de $5,40 \mathrm{~m}$ a $5,60 \mathrm{~m}$ entre fileiras e de $2,0 \mathrm{~m}$ a $3,80 \mathrm{~m}$ na linha de plantio.

\subsubsection{Condução do planitio}

Durante o desenvelvimento do plantio, foram rea lizados cultivos intercalares de milho, soja e arroz, no primeiro, segundo e terceiro anos, respectivamente. 0 preparo de ärea para esses cultivos, foi constituído de uma aração e uma a duas gradagens. 0 controle de pragas e doenças e a aplicação de fertilizantes, nesse periodo, foram exclusivos para os cultivos intercalares. Na fase posterior à colheita, procedeu-se o enterrio dos restos de cultura com a grade. No período intermediārio entre um e outro cultivo, foram realizadas roçagens mecãnicas, quando necessärio. No cultivo da seringueira, realizou-se apenas o replantio de mudas apōs a geada de 1981, desbrotas periödicas e capina das linhaside plantio. No quarto ano apōs a decapitação, a manutenção das entrelinhas foi efetuada atravēs da realização de 4 gradagens e, no quinto e sex to anos, quando ocorreu o fechamento das copas (formação do 
dossel), foi realizada uma roçagem mecânica. Nesses três ültimos anos não foi procedida adubação das seringueiras e devi do a não ocorrência de doenças em caräter epidêmico e de pragas, não foi efetuado controle fitossanitärio.

\subsubsection{Delineamento experimental}

Face a indisponibilidade de um local com caracteristicas para o uso de outro delineamento, assumiu-se trabaIhar numa àrea que possibilitasse o emprego do delineamento experimental inteiramente ao acaso. Foram utilizados 9 tratamentos e 10 plantas por tratamento, sendo a anălise procedida como: "Classificação de um critério" ou "Experimento de um fator", segundo SPIEGEL (1978).

\subsubsection{Tratamentos}

Como tratamentos para a sangria por puntura, foram utilizadas variações em relação ao comprimento de fai$x a(70 \mathrm{~cm}$ e $100 \mathrm{~cm})$, nümero de punturas $(6 \mathrm{P}$ e $12 \mathrm{P})$ e concentração do estimulante (ET2, $5 \%$ e ET $5 \%$ ). As quantidades do estimulante (1,5g para a faixa de $70 \mathrm{~cm}-\mathrm{Ta} 1,5 / 1$ e $2,0 \mathrm{~g}$ para $100 \mathrm{~cm}$ - Ta 2,0/1) foram correspondentes aos comprimentos de faixas. As combinações destas variáveis foram comparadas ao controle experimental, ou seja, a sangria convencional sem es 
timulação $(1 / 2 s \quad d / 26 \mathrm{~d} / 7)$. Devido a paralização da sangria no periodo seco, não foi seguido a periodicidade de 11 meses de sangria com um de repouso $(11 \mathrm{~m} / 12)$. A sequência utilizada para os tratamentos é descrita na tabela 4 e uma representação visual è apresentada na figura 2 .

Tabela 4. Esquema dos tratamentos utilizados no experimento.

1. $6 P /(70 \times 1) . d / 26 d / 7 . E T .2,5 \%$. Ta $1,5 / 1$

2. $12 p /(70 \times 1) \cdot d / 26 d / 7 . E T 2,5 \%$. Ta $1,5 / 1$

3. $6 p /(70 \times 1) . d / 26 d / 7 . E T 5 \%$. Ta $1,5 / 1$

4. $12 p /(70 \times 1) . d / 26 d / 7 . E T 5 \%$. Ta $1,5 / 1$

5. $6 P /(100 \times 1) . d / 26 d / 7 . E T \cdot 2,5 \%$. Ta $2 / 1$

6. $12 p /(100 \times 1) . d / 26 d / 7$.ET $2,5 \%$. Ta $2 / 1$

7. $6 P /(100 \times 1) . d / 26 d / 7 . E T 5 \%$. Ta $2 / 1$

8. $12 p /(100 \times 1) . d / 26 d / 7$.ET $5 \%$. Ta $2 / 1$

9. $1 / 2 s \cdot d / 26 d / 7$

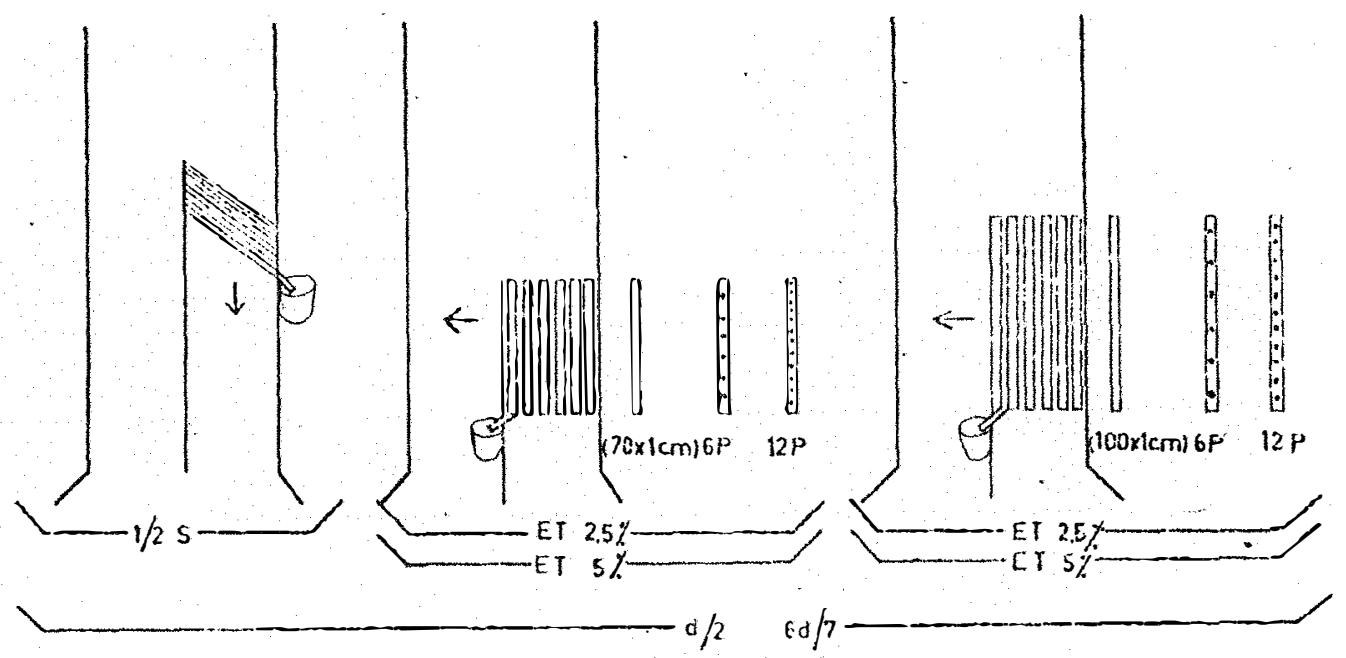

Figura 2. Representação dos tratamentos utilizados no experimento. 


\subsubsection{Instalação e condução do experimento}

Inicialmente procedeu-se a seleção das plantas atravēs da mensuração do perímetro do tronco à altura de $130 \mathrm{~cm}$ do ponto de união enxerto x porta-enxerto (calo de enxertia). Naquela oportunidade, a mëdia de perímetro do tronco para tratamentos variou de $39,2 \mathrm{~cm}$ a $41,8 \mathrm{~cm}$; as plantas apresentavam-se com idade variando de 5,5 a 6 anos após decapitação do viveiro para estabelecimento do plantio definiti vo .

Para a sangria convencional, realizou-se abertura de painel em meia espiral do tronco à altura de 130 cm do calo de enxertia, com posterior equipagem das plantas à sangria. Os cortes foram realizados na declividade e profundidade preconizados para este sistema, conforme descrito por VIRGENS FILHO e CASTRO (1986). A frequência de sangria foi em d/2 $6 \mathrm{~d} / 7$, tendo sido igual para ambos os métodos de sangria. Para a sangria por puntura, fez-se a raspagem das faixas verticais com l cm de largura (figura $3 a$ ), e comprimentos variando em função dos tratamentos $(70 \mathrm{~cm} \mathrm{e} 100 \mathrm{~cm})$, sendo a parte inferior das faixas localizada à altura de $30 \mathrm{~cm}$ do calo de enxertia, onde foram localizadas as bicas e as tigelas. No primeiro mês realizou-se a estimulação com ethephon $10 \%$. Nos meses subsequentes, novas faixas foram abertas, com distảncia de l cm em relação a faixa anterior, à direita. As es timulações passaram a ter concentrações de ethephon $2,5 \%$ e 
5\%, sendo o emprego destas em função dos tratamentos. A apl cação de estimulante foi realizada atravēs de pincelamento na faixa (figura 3b). Quatro tratamentos foram conduzidos com a realização de 6 punturas e outros quatro com 12 punturas. 0 instrumento utilizado para puntura constitui-se de um estilete de aço de $1 \mathrm{~mm}$ de diâmetro e comprimento de $6 \mathrm{~mm}$, introduzido em um cabo de madeira com $8 \mathrm{~mm}$ de diàmetro e $12 \mathrm{~cm}$ de comprimento (figura 3c). Uma visão do painel explorado através da sangriapor puntura $\vec{e}$ apresentada na figura $3 d$. A cada sangria,fez-se a adição de ācido acético a $10 \%$ na tigela para coagulação do lātex; os coāgulos formados foram enfiados em arame 14, envolto no tronco, acima do painel de sangria e as produções diärias foram pesadas mensalmente. Em cinco das onze pesagens mensais, observou-se a variação da produção em função dos dias apōs a estimulação. Mensalmente, foram obser vadas as condições do painel com respeito a ocorrência de doenças (cancro do painel, mofo cinzento e secamento de painel) e as reações da casca ao sistema de sangria (espocamento, inchaço e fendilhamento de cascal e lesões mecânicas decorrentes do uso da faca jebong.

Sob condições de baixa temperatura e prolongado período seco, a sangria foi paralizada por solicitação do pro dutor e em decorrência da queda de produção observada nos seringais da região, no mês de julho. A paralização prolongouse durante os meses de julho a setembro. A sangria foi reini ciada em outubro, e prosseguiu até o mês de fevereiro, quando o experimento teve os trabalhos de campo concluídos. 

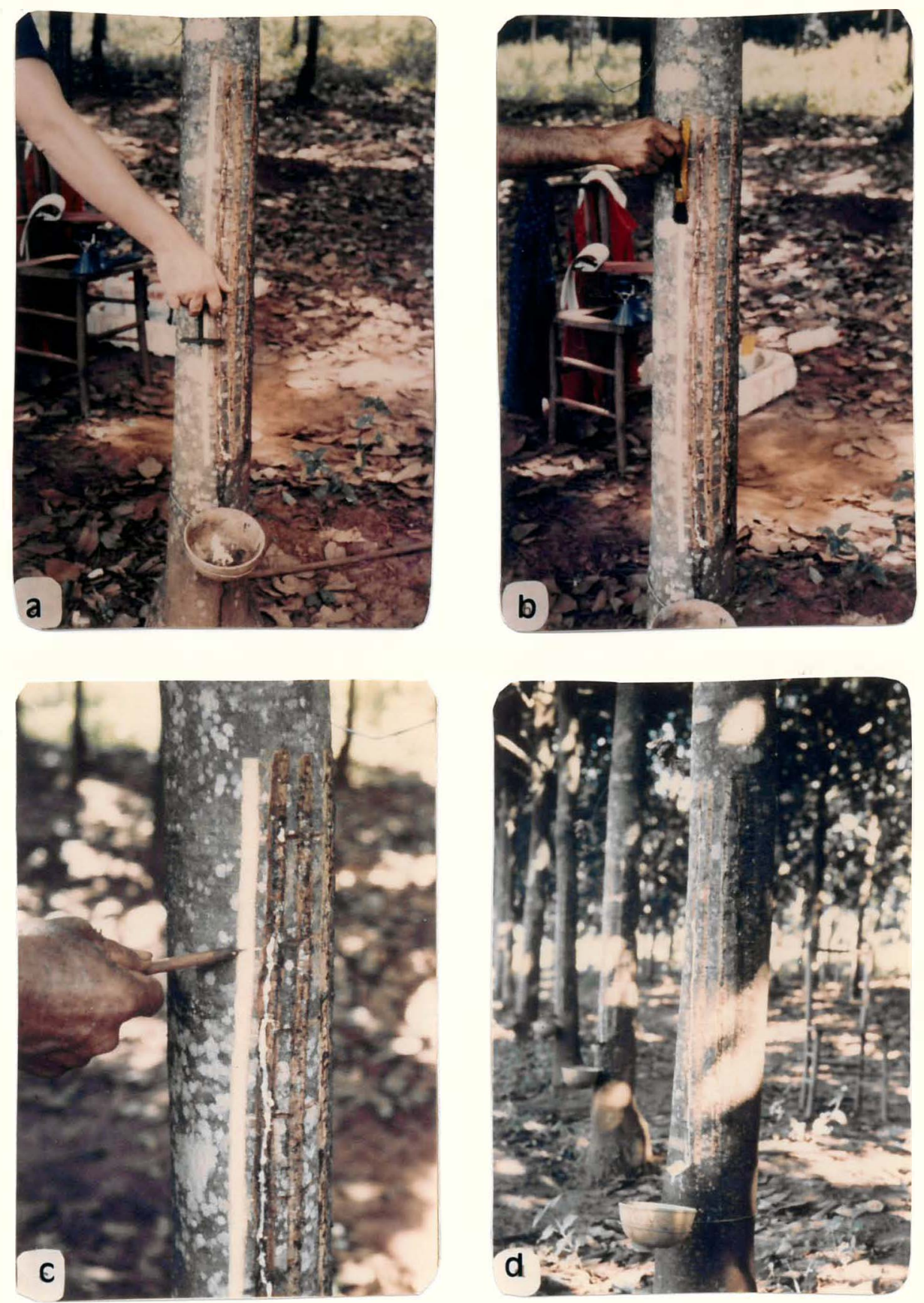

Figura 3. a - abertura de faixa na SPP; b - aplicação do esti mulante; c - instrumento utilizado na realização das punturas; d - visão do painel de exploração atra vēs da SPP. 
Com referência as propriedades do làtex, analisou-se o conteüdo de borracha seca, tambëm chamado DRC ("dry rubber content"), o qual foi determinado atravēs da coagulação de um dado oeso do látex com solução diluída de ácido acético, obtendo-se uma lâmina de borracha apös secagem à temperatura de 75:C (SILVEIRA, 1979).

Ao final do experimento, fez-se a coleta de amostras de casca para análise da casca virgem e da casca regenerada. As análises foram realizadas em laboratörio do Cen tro Nacional de Pesquisas de Seringueira e Dendê. Tambēm pró cedeu-se uma avaliação conclusiva em relação as condiçöes do painel de sanaria e fez-se a determinação do incremento do tronco, apōs nova avaliação do perímetro à altura de $130 \mathrm{~cm}$ do calo de enxertia.

\subsubsection{Anālise estatística}

A anālise de variância foi realizada segundo a técnica empregada para "Experimento de um fator". 0 esquema adotado é apresentado na tabela 5 .

Para anälise da produção envolvendo apenas os tratamentos da sangria por puntura, utilizou-se o arranjo fatorial conforme esquema da tabela 6.

As médias dos tratamentos foram comparadas pe10 teste de Tukey ao nivel de $5 \%$ de probabilidade de acordo com PIMENTEL GOMES (1976) e STEEL e TORRIE (1980). 
Tabela 5. Esquema da análise de variancia empregado para analisar separadamente a produção e o crescimento do tronco.

Causas da Variação

G.L.

Tratamentos

8

Residuo

81

Total

Tabela 6. Esquema da análise de variância empregado para estu do de interações entre os caracteres envolvidos na sangria por puntura em relação à produção.

Causas da Variação

G.L.

Altura

Estimulação

Puntura

Altura x Estimulação

Altura $x$ Puntura

Estimulação $x$ Puntura

Altura $x$ Estimulação x Puntura

Residuo

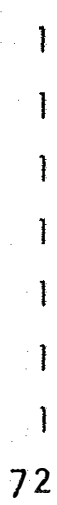

Total 79 


\subsubsection{Estudo de correlação}

os parâmetros referentes a produção e incremento do crescimento do tronco foram correlacionados entre si, determinando-se o coeficiente de correlação ( $r$ ) linear simples. 


\section{RESULTADOS E DISCUSSÃO}

\subsection{P.RODUGÃO DE BORRACHA}

os dados relativos a produção de borracha em gramas por sangria e por planta, são apresentados na figura 4. A anälise de variāncia envolvendo os tratamentos da sangria por puntura e da sangria convencional é mostrada na tabe la 7, onde observa-se alto nível de significância entre trata mentos, evidenciando que alguma combinação linear de médias é significativa. 0 conjunto de dados analisados apresenta uma distribuição normal, sendo porisso desnecessārio o uso de transformações; ainda assim, ao se realizar a transformação segundo $\sqrt{x}$, obteve-se uma redução no coeficiente de variação de $55,37 \%$ para $25,32 \%$, contudo, os resultados foram semelhan tes àqueles obtidos com os dados não transformados.

Na aplicação do teste de Tukey para médias de trä tamentos (tabela 8), não se observou diferença significativa 


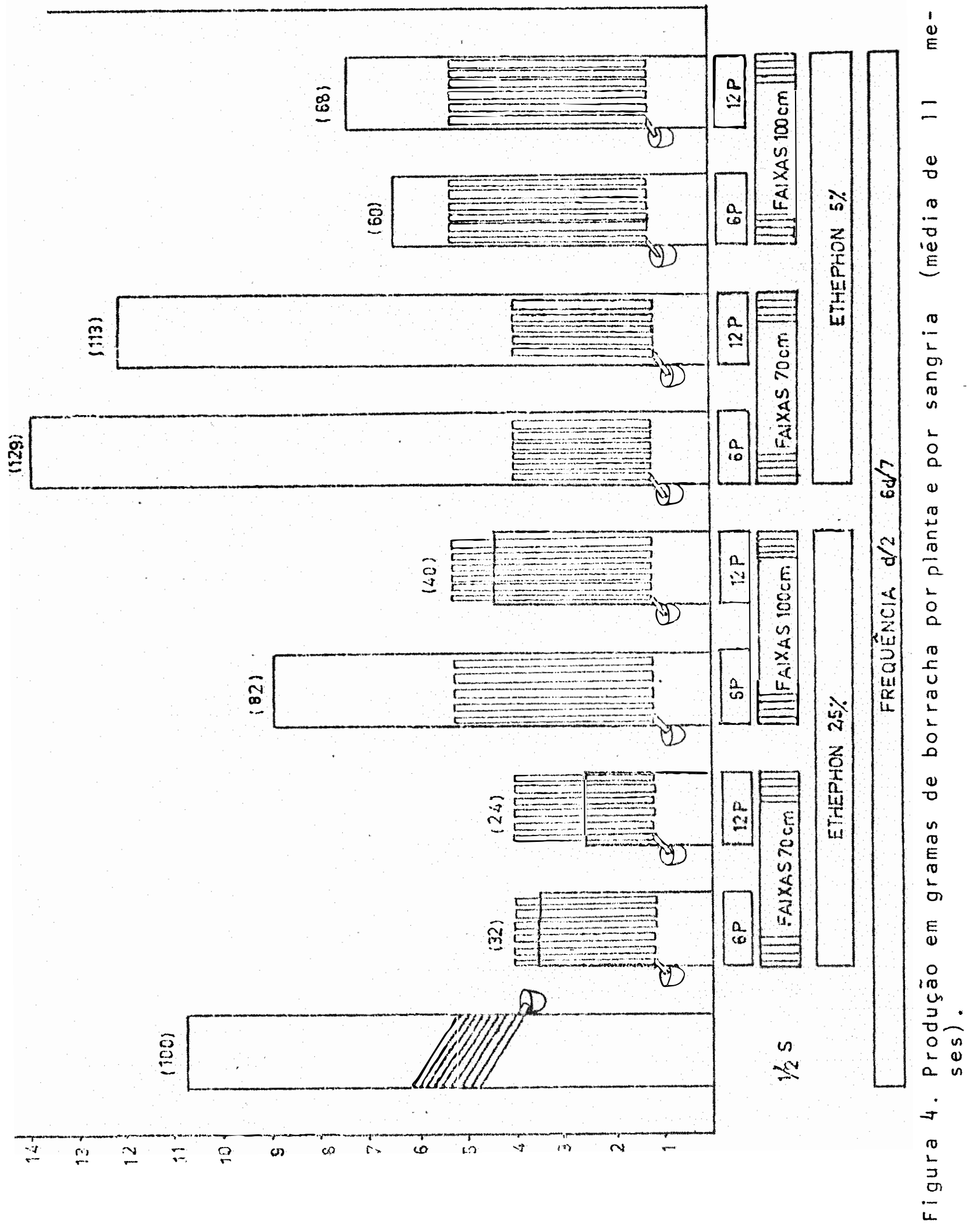


Tabela 7. Análise de variancia para médias de produção de borracha seca (g/sangria/planta), envolvendo os sistemas de sangria por puntura e de sangria convencional.

Causas dá Variação

G.L.

S.Q.

Q.M.

\begin{tabular}{lrrl}
\hline Tratamentos & 8 & 1252,00 & $156,50 * *$ \\
Residuo & 81 & 1491,97 & 18,41 \\
\hline Total & 89 & 2743,97 & \\
\hline
\end{tabular}

Significativo ao nivel de $1 \%$ de probabilidade.

ao nivel de $5 \%$ entre os tratamentos $3,4,9$ e 5 , sendo que os três ültimos também não diferiram dos tratamentos 8 e 7 . Ainda neste nivel de significância, os tratamentos 5,8 e 7 não diferiram dos tratamentos 6 e 1 e, entre estes, apenas 05 diferiu do tratamento 2, considerado em termos absolutos como o menos indicado, enquanto o tratamento 3 foi o de maior supe rioridade.

Numa estimativa da produção de borracha por hectare (tabela 9 ), observa-se que apenas os tratamentos 3,4 e 9 são potenciais à obtenção de produções satisfatōrias, res salvando-se que o tratamento $9(1 / 2 \mathrm{~s} \cdot d / 26 \mathrm{~d} / 7)$, não ë ut lizado em plantas com perimetro do tronco inferior a $45 \mathrm{~cm}$ (mensuração realizada à altura de $130 \mathrm{~cm}$ do ponto de união en 
Tabela 8. Teste de Tukey para anälise de tratamentos em relação a produção de borracha.

Produção em

g/sangria/planta
3. $6 \mathrm{p} /(70 \times 1) . d / 6 \mathrm{~d} / 7 . \mathrm{ET} 5 \% . \mathrm{Ta} 1,5 / 1$

4. $12 \mathrm{p} /(70 \times 1) \cdot d / 26 \mathrm{~d} / 7 . \mathrm{ET} 5 \%$. Ta $1,5 / 1$

9. $1 / 2 \mathrm{~s} . d / 26 d / 7$

5. $6 p /(100 \times 1) . d / 26 d / 7$. ET $2,5 \%$. Ta $2 / 1$

8. $12 \mathrm{P} /(100 \times 1) . d / 26 \mathrm{~d} / 7$. ET 5\%.Ta $2 / 1$

7. $6 \mathrm{P} /(100 \times 1) . d / 26 d / 7 . E T 5 \%$. Ta $2 / 1$

6. $12 p /(100 \times 1) . d / 26 d / 7$. ET $2,5 \%$. Ta $2 / 1$

1. $6 p /(70 \times 1) \cdot d / 26 d / 7$.ET 2,5\%. Ta 1,5/1

2. $12 P /(70 \times 1) . d / 26 d / 7$ ET $2,5 \%$. Ta $1,5 / 1$
13,85 a

$12,12 a b$

10,76 ab

8,81 abc

7,36 bcd

6,46 bcd

$4,36 \quad \mathrm{~cd}$

3,47 cd

$2,54 \quad d$

Médias seguidas de letras minúsculas distintas têm diferença significativa ao nível de $5 \%$ de probabilidade.

C.V. $=55,37 \%$

xerto/porta-enxertol. As produções computadas em borrachacoa gulada no campo, tiveram um equivalente em borracha seca em torno de $78 \%$. Dessa maneira, pode-se esperar para os tratamentos 3 e 4 uma produtividade em torno de $583 \mathrm{~kg}$ e $510 \mathrm{~kg}$ de borracha seca/ha/ano ou 874 e $765 \mathrm{~kg}$ de borracha seca/ha em 18 meses de sangria, respectivamente. Entretanto, a neces sidade de maior número de punturas para o tratamento 4 (12P) $(70 \times 1)) . d / 26 d / 7 . E T 5 \%$. Ta $1,5 / 1)$, constitui uma desvantagem do ponto de vista operacional, alëm de favorecer a ocorrência de danos à casca. Assim, define-se o tratamento $3(6 p /(70 \times 1) . d /$ 


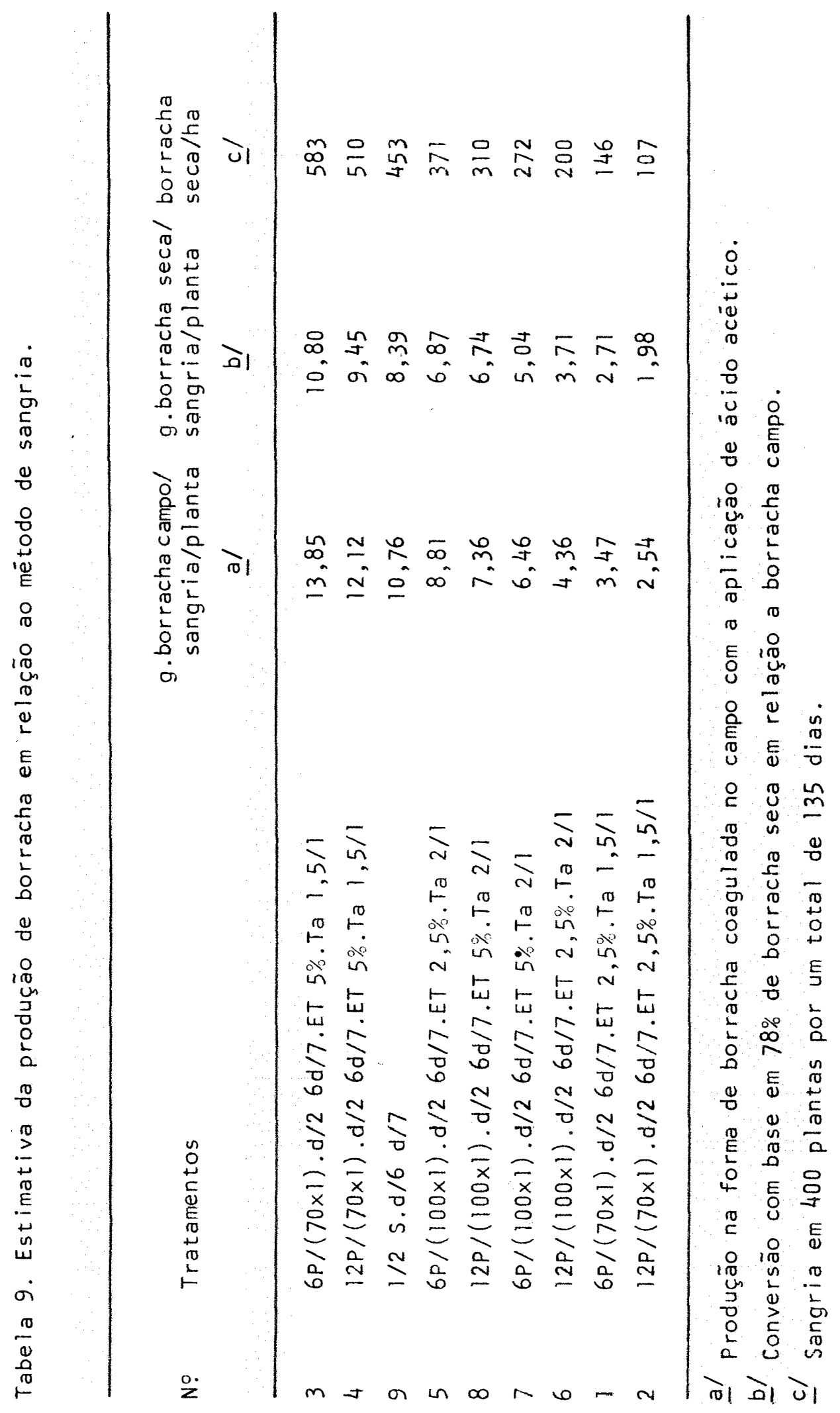


$126 \mathrm{~d} / 7 . \mathrm{ET} 5 \%$. Ta $1,5 / 1)$, como o sistema promissor para uso na sangria precoce segundo as condições deste trabalho. As produtividades obtidas podem ser a inda incrementadas pela adequada aplicação de fertilizantes no seringal.

\subsubsection{Variações mensais na produção}

No início de exploração da seringueira, o làtex obtido é muito viscoso, mais concentrado e com fluxo pouco duradouro. Com as subsequentes sangrias, a frequências regulares, ocorre aumento na produção de lätex até alcançar um vo lume compatível com as condiçōes de exploração. Nesse período o látex vai se tornando mais diluído, até quando atinge uma posição de equilíbrio, mas, hä um. incremento na produção final, uma vez que a redução na concentração do làtex é compensada pelo maior volume produzido (BUTTERY e BOATMAN, 1976; MORAES, 1980).

Na sangria em espiral, essa fase de baixa produção inicial não ẽ duradoura, embora, a depender do cultivar, progressivos aumentos possam ainda ocorrer até determina do limite, com o passar do tempo. Na sangria por puntura, a produção dos seis primeiros meses é inferior às produçōes obtidas a partir desse período. Neste trabalho, observou-se que mesmo com a utilização de ethephon $10 \%$ no primeiro mês de sangria por puntura, as produções nos seis primeiros meses a inda não foram significativas. No caso de $6 \mathrm{P} /(70 \times 1) . d / 26 \mathrm{~d} /$ 
/7.ET $5 \%$. Ta $1,5 / 1$, as produções no primeiro semestre ficaram em torno de $9,8 \pm 1,53 \mathrm{~g} / \mathrm{s} / \mathrm{pl}$; no segundo semestre, houve um período de paralização da sangria (julho, agosto, setembro), em virtude da seca, sendo a sangria reiniciada com baixa produção em outubro, como seria esperado. Nos meses seguintes, registrou-se uma produção sempre superior em 1,5 vezes à mëdia do semestre anterior. Estas informações comprovam a necessidade de uso de uma maior concentração do estimulante, nelo menos nos quatro meses de uso da SPP, como sugerido por ABRAHAM e ANTHONY (1981). Concentrações de $7,5 \%, 5 \%$ e $3,3 \%$ de ethephon podem ser investigadas para uso no primeiro, segundo e terceiro semestres, respectivamente, tendo por objet $\underline{i}$ vo a obtenção de maiores produções, reduzindo-se os riscos em relação ao efeito cumulativo de altas concentrações de e thephon.

\subsubsection{Variação semanal na produção}

Na sangria por puntura, as produções obtidas foram marcadamente superiores nas duas primeiras semanas após estimulação, quando então experimentaram decrëscimos, chegando a atingir niveis bastante baixos na quarta semana. Essas variaçoes foram independentes da concentração do estimulante (figura 5). Na sangria convencional as produções foram mais estäveis. 


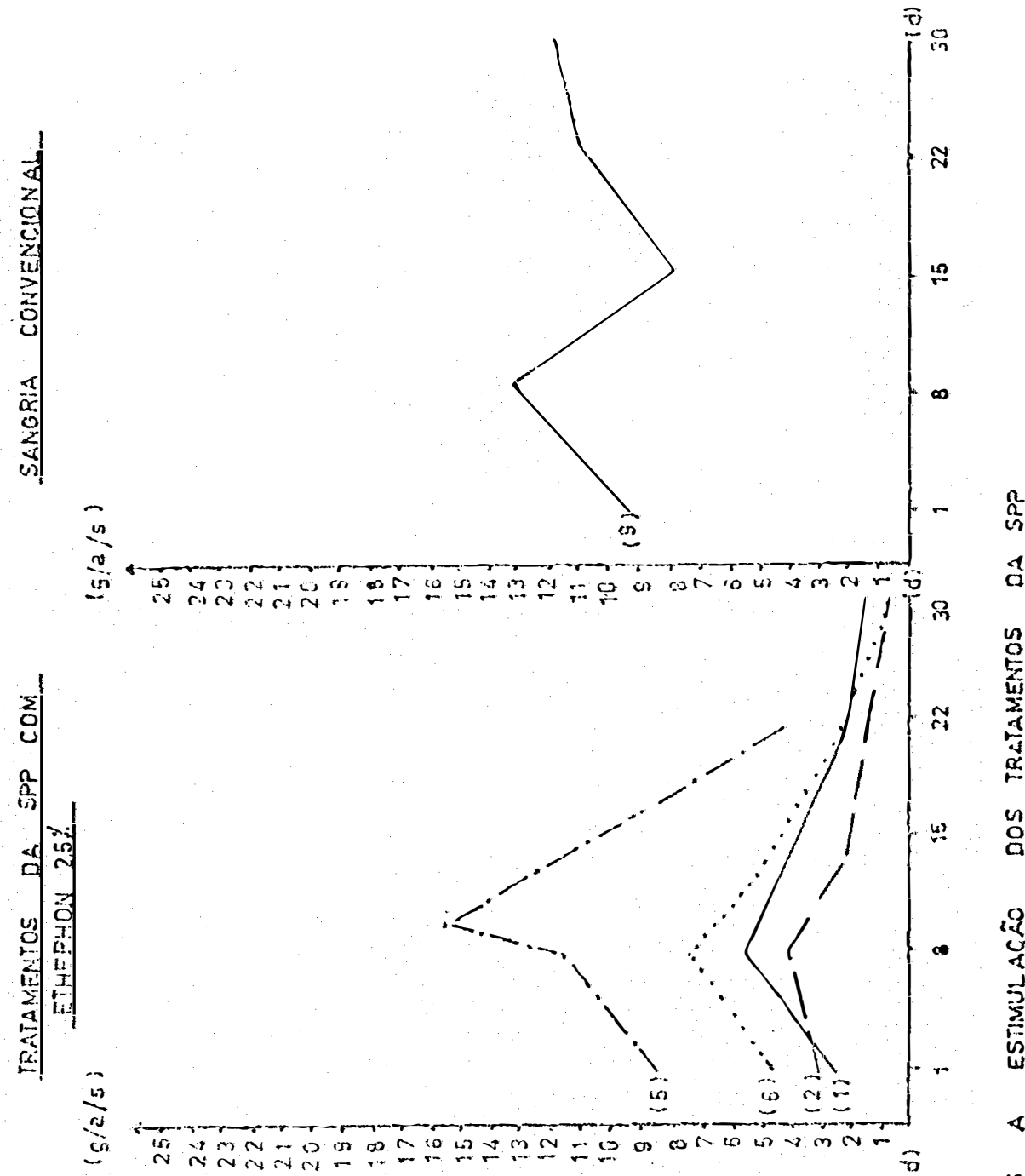

$n$
$a$
$a$
$a$

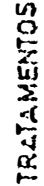

옹

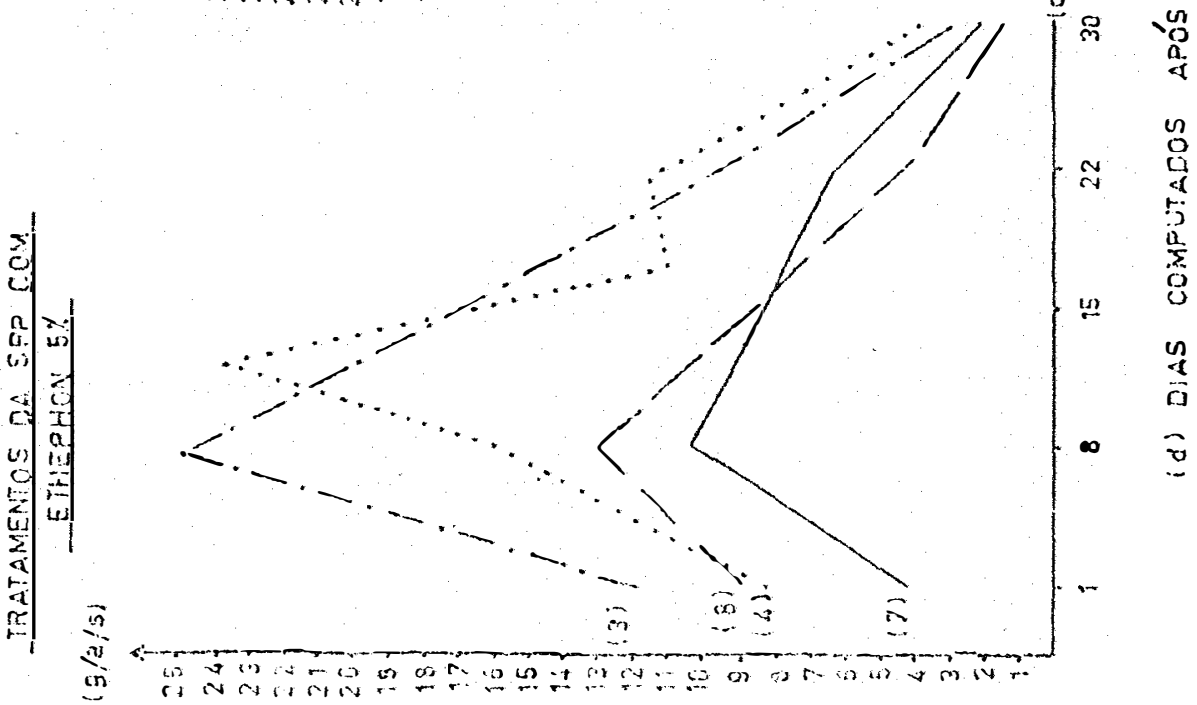

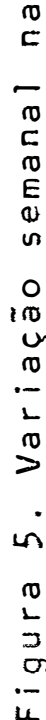


Uma opinião comum entre diversos autores é que a sangria por puntura deve ter um ciclo mäximo de três semanas apōs a estimulação, sendo a semana seguinte utilizada para repouso das plantas exploradas. Isso possibilita um aumento na produção em sangria por planta, maior crescimento e melhor utilização do seringueiro. Um esquema de alternância foi proposto por ABRAHAM e ANTHONY (1981), sugerindo o uso de 4 tarefas por seringueiro, enquanto MORAES (1985), propös o uso de 3 tarefas, ficando neste caso, uma periodicidade de 3 s/4 (três semanas de exploração num total de quatro), $3 \mathrm{~s} / 5$, para cada tarefa. Na frequência d/2 $6 \mathrm{~d} / 7$, este é o esquema mais viä vel, devendo portanto ser adotado na sangria por puntura.

\subsubsection{Influência da concentração do estimulante, nümero de punturas e comprimento de faixa na produção}

Numa anälise em arranjo fatorial envolvendo os fatores estudados na $\operatorname{SPP}($ tabela 10), observou-se significância ao nível de $1 \%$ para estimulação e para a interação altura $x$ estimulação, enquanto o fator puntura e a interação altura $x$ estimulação x puntura foram significativos ao nível de $5 \%$; os demais fatores isolados e as demais interações não se mostraram significativos. No desdobramento desta anälise, fezse a comparação de médias entre diferentes fatores e variäveis pelo testedeTukey ao nivel de $5 \%$ (tabela 11 ). Com base 
nos resultados obtidos, verificou-se que a concentração do es timulante foi o mais importante fator determinante da produção, sendo o único a apresentar significância quando comparado o mesmo fator com a mesma variävel.

Tabela 10. Anālise de variancia para produção de borracha (g/ sangria/planta), envolvendo os tratamentos da sangria por puntura.

Causas da Variação

G.L.

S.Q.

Q.M.

Altura

Estimulação

Puntura

Altura x Estimulação

Altura $x$ Puntura

Estimulação x Puntura

Altura x Estimulação $x$ Puntura

Residuo

$$
31,06
$$

31,06

1

1

530,70

48,15

465,94

1,00

25,75

47,23

927,16

72

$$
792076,99
$$

Total

* Significativo ao nivel de $5 \%$ de probabilidade

** Significativo ao nivel de $1 \%$ de probabilidade. 


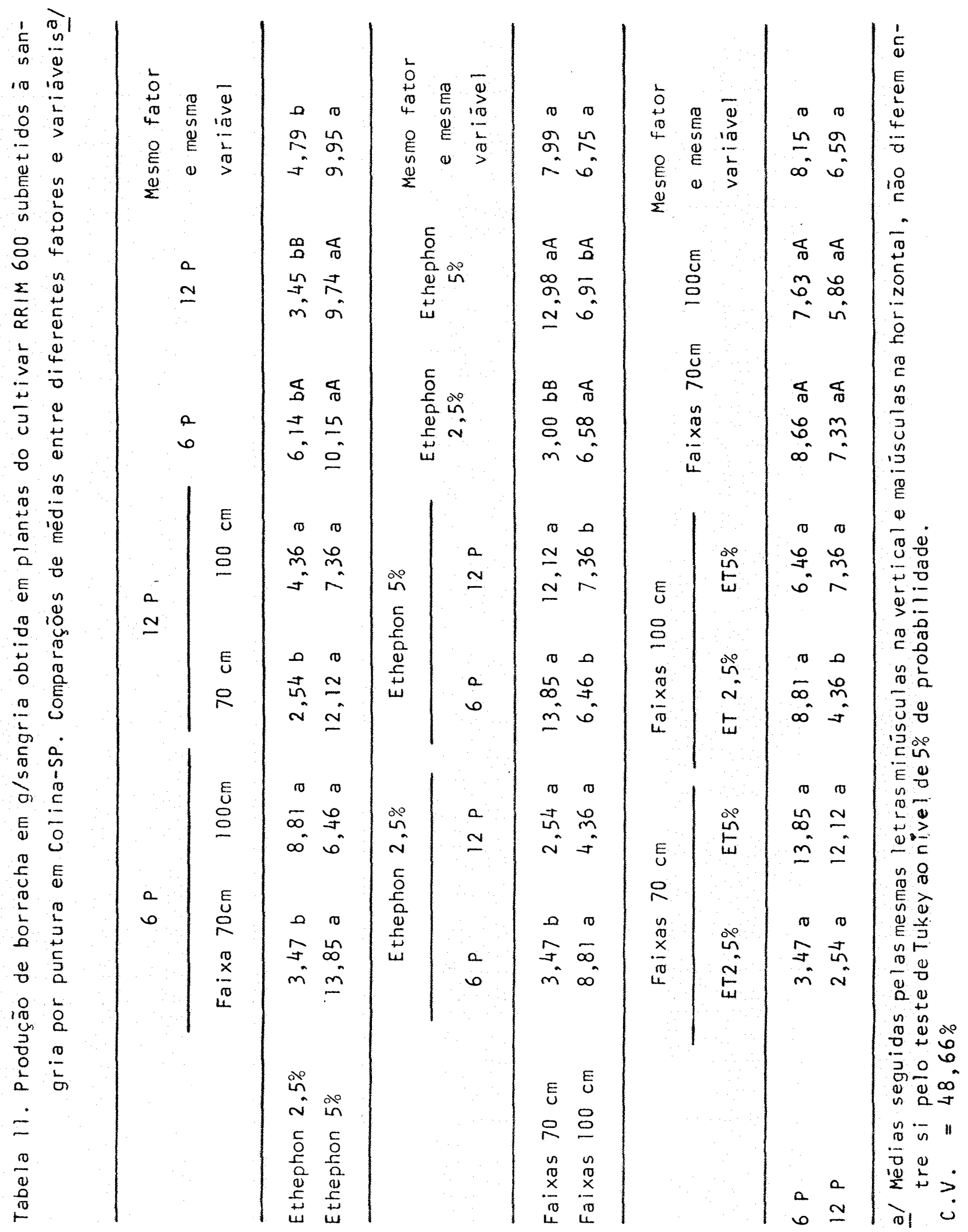


$\mathrm{Na}$ comparação de médias envolvendo as duas concentrações do estimulante com 6 e 12 punturas, respectivamen te, verificou-se que ethephon $5 \%$ foi superior a $2,5 \%$; estes resultados ficaram evidentes dentro do comprimento de faixa de $70 \mathrm{~cm}$, enquanto para $100 \mathrm{~cm}$, não houve diferença significativa. Presume-se que para o menor comprimento de faixa, o efeito de ethephon $5 \%$ resultou em maior ampliação da ārea de drenagem, superando assim o efeito de ethephon $2,5 \%$. 0 maior nível de concentração do estimulante anulou ainda o efeito dos dois niveis de punturas (6P e $12 p)$, para os quais, não ocor reram diferenças significativas dentro dos dois comprimentos de faixas. A concentração do estimulante tem influência prio ri täria na produção, conforme tambēm observado por WAIDYANATHA e ANGAMMANA (1981) e SARAMANAYAKE (1985). 0 aumento na dose utilizada por planta pode proporcionar um incremento linearaté determinado limite, devendo-se entretanto, investigar o efeito de altas dosagens por um período cumulativo. Por sua vez, na concentração de ethephon $5 \% \operatorname{com} 6$ ou 12 punturas, respect vamente, as produções em faixa de $70 \mathrm{~cm}$ foram estatisticamente superiores àquelas em faixa de $100 \mathrm{~cm}$, sendo isso em parte, devido as maiores perdas por escorrimento de lätex para fora da faixa, o que ocorreu sobretudo nos tratamentos com ethephon $5 \%$, com os quais verificou-se quase sempre um maior volu me de làtex escoado. Este problema foi motivado pela pequena espessura de casca, sendo este um problema agravante para a adoção da SPP em São Paulo, pois mesmo nos tratamentos com fai 
xas de $70 \mathrm{~cm}$, necessita-se de maiores cuidados para reduzir as perdas por extravazamento na faixa.

Com ethephon $2,5 \%$, o uso de 6 punturas dentro de faixa de $100 \mathrm{~cm}$ foi estatisticamente superior a 6 punturas em faixa de $70 \mathrm{~cm}$, evidenciando que para o menor nível de concentração do estimulante e menor nümero de punturas, o incremento na àrea de drenagem foi compensado pelo maior comprimento de faixa, havendo nesse caso, menores perdas por escorrimento de látex face ao menor nível de produção que ocorreu em quase todos os tratamentos com ethephon 2,5\%. 0 aume $\underline{\mathbf{n}}$ to considerado ficou em torno de $50 \%$. Todavia, incremento de produção pelo uso de maior comprimento de faixa não é linearmente proporcional ao acréscimo no comprimento, podendo se obter no máximo, uma diferença de produção de $30 \%$. Para efei to de discussões, deve-se considerar que as plantas da parcela $6 \mathrm{P} /(70 \times 1) . d / 26 \mathrm{~d} / 7 . \mathrm{ET} 2,5 \%$. Ta $1,5 / 1$ apresentaram uma potencial inferioridade quando da realização do teste em branco, sendo isso uma provável causa para este resultado.

Na comparação de diferentes nümeros de punturas dentro de ethephon $2,5 \%$ e faixa de $100 \mathrm{~cm}$, observou-se que o uso de 6 punturas foi estatisticamente superior a 12 punturas. Embora não tenha havido diferença significativa, esta mesma tendència foi observada nos tratamentos com ethephon $2,5 \%$ e $5 \%$ em faixa de $70 \mathrm{~cm}$, respectivamente. Estas informaçöes coincidem com os resultados obtidos por HASHIM et alii (1979), que obtiveram produção superior com o uso de 5 puntu- 
ras em comparação a 10 e 15 punturas, respectivamente em fai$x$ a de $100 \mathrm{~cm}$. Em contraste, nos tratamentos com ethephon 5\% e faixa de $100 \mathrm{~cm}$, o uso de 12 punturas foi superior a 6 punturas, sendo este resultado devido a exploração de uma ärea de drenagem ampliada em decorrência da interação entre o maior comprimento de faixa e a maior concentração de ethephon.

\subsection{Crescimento do tronco}

Na tabela 12 encontram-se os resultados da anä lise de variância relativos ao incremento no crescimento do tronco. A aplicação do teste $F$ revelou um alto nível de significância entre os tratamentos. Na aplicação do teste de Tukey ao nível de 5\% (tabela 13), observou-se que os tratamentos 9 , $4,2,6,8,1,5$ e 7 não diferiram estatisticamente, ao passo que os seis ültimos tambēm não diferiram do tratamento 3. Assim, ap̣enas os tratamentos 9 e 4 foram estatisticamente superiores ao 3 .

A natureza dessas informações impossibilita afirmar que houve uma absoluta superioridade do incremento no crescimento do tronco em plantas submetidas a sangria convencional quando comparadas àquelas submetidas à sangria por pun tura. Entretanto, para o mais alto nível de produção obtido com a sangria por puntura (tratamento 3 ), observou-se que as plantas submetidas a este método de sangria tiveram um cresci mento do tronco inferior àquele das plantas submetidas à sangria convencional (tratamento 9 ). 
Tabela 12. Anälise de variáncia para incremento no perímetro do tronco em $\mathrm{cm}(\mathrm{Fev} / 85$ a Fev/86).

\begin{tabular}{lccc} 
Causas da variação & G.L. & S.Q. & Q.M. \\
\hline $\begin{array}{l}\text { Tratamentos } \\
\text { Residuo }\end{array}$ & 8 & 101,73 & $12,71^{\star *}$ \\
\hline Total & 81 & 331,05 & 4,08 \\
\hline
\end{tabular}

** Significativo ao nivel de $1 \%$ de probabilidade

Tabela 13. Teste de Tukey paramëdias de tratamentos em relação ao incremento no perímetro do tronco $(\mathrm{cm})$ envolven do todos os tratamentos estudados.

\begin{tabular}{lc}
\hline N:/Tratamentos & $\begin{array}{c}\text { Incremento no perime- } \\
\text { tro do tronco (cm) de } \\
\text { fev } / 85 \text { a fev/86 }\end{array}$ \\
\hline
\end{tabular}

9. $1 / 2 s . d / 26 d / 7$

6,55 a

4. $12 P /(70 \times 1) . d / 26 d / 7$.ET 5\%.Ta $1,5 / 1$

6,30 a

2. $12 p /(70 \times 1) \cdot d / 26 d / 7 . E T 2,5 \%$. Ta $1,5 / 1$

6,15 ab

6. $12 p /(100 \times 1) . d / 26 d / 7$.ET $2,5 \%$. Ta $2 / 1$

5,70 ab

8. $12 P /(100 \times 1) . d / 26 d / 7$.ET 5\%.Ta2/1

$4 ., 65 a b$

1. $6 P /(70 \times 1) . d / 26 d / 7$.ET $2,5 \%$. Ta $1,5 / 1$

4,65 ab

5. $6 P /(100 \times 1) \cdot d / 26 d / 7$. ET 5\%. Ta $2 / 1$

4,45 ab

7. $6 P /(100 \times 1) . d / 26 d / 7$. ET 5\%.Ta $2 / 1$

4,05 ab

3. $6 P /(70 \times 1) . d / 26 d / 7$.ET 5\%. Ta 1,5/1

$3,30 \quad b$

Médias seguidas de letras minüsculas distintas têm diferença significativa ao nivel de $5 \%$ de probabilidade.

C.V. $=39,72 \%$ 
Efeito depressivo no crescimento do tronco devido a sangria por puntura em plantas com perímetro inferior a $40 \mathrm{~cm}$, fol reportado por RAMACHANDRAN e LEE (1979), WENXIAN e JINGUI (1981) e VERNOU e TONNELIER (1985), em relação ao cultivar GT l e SOARES (1985), em relação ao 'Fx 3899'. Hai, citado por RAMACHANDRAN e LEE (1979), ressaltou a relação inversa entre o crescimento e a produção, sobretudo em plantas mais produtivas submetidas a SPP e com perímetro do tronco inferior a $45 \mathrm{~cm}$.

E evidente que a mëdia de ll meses de sangria registrada para o tratamento de maior produção na SPP, mesmo sendo superior à média obtida com a sangria convencional, não foi suficientemente alta para ser considerada dentro de um ni vel de produção que comprometesse o crescimento. Todavia, de ve-se ressaltar a existência de um prolongado período seco, seguido do retorno à exploração, quando as médias registradas, notadamente para o tratamento 3, foram mais elevadas em relação àquelas obtidas no primeiro semestre. Nessa "fase, o crescimento normal das plantas foi parcialmente prejudicado pe lo desvio de parte dos produtos elaborados para manutenção da produção.

\subsection{Correlação entre a producẽo e o crescimento}

$\mathrm{Na}$ tabela 14 ë apresentado o coeficiente decor 
relação determinado entre os parâmetros: produção e crescimen to. O coeficiente calculado fil negativo para os tratamentos $1,3,4,6$ e 9 e positivo para os tratamentos 2 e 5. Entretan to, na anälise atravēs do testo "t" não observou-se significân cia ao nível de 5\%, evidenciando que ambos os parâmetros não estavam correlacionados. Por outro lado, verificou-se significância ao nível de $5 \%$ para os tratamentos 7 e 8 , para os quais houve correlação positiva entre a produção e o crescimento do tronco.

Tabela 14. Estudo de correlação entre os parâmetros: produção e crescimento do tronco.

N:/Tratamentos

Coeficiente de

correlação $(r)$

1. $6 \mathrm{P} /(70 \times 1) . d / 26 d / 7 . E T 2,5 \%$. Ta $1,5 / 1$

$-0,19505562 n . s$.

2. $12 p /(70 \times 1) . d / 26 d / 7$. ET 2,5\%.Ta $1,5 / 1$

0,03054767 n.s.

3. $6 \mathrm{p} /(70 \times 1) \cdot d / 26 \mathrm{~d} / 7$. ET $5 \%$. Ta $1,5 / 1$

$-0,22929896 n . s$.

4. $12 p /(70 \times 1) \cdot d / 26 d / 7$.ET 5\%.Ta 1,5/1

$-0,18638766 \mathrm{n} . \mathrm{s}$.

5. $6 P /(100 \times 1) \cdot d / 26 d / 7 . E T 2,5 \%$. Ta $2 / 1$

$0,17730833 \mathrm{n} . \mathrm{s}$.

6. $12 p /(100 \times 1) \cdot d / 26 d / 7$.ET $2,5 \%$. Ta $2 / 1$

$-0,24489292 \mathrm{n} . \mathrm{s}$.

7. $6 p /(100 \times 1) . d / 26 d / 7$.ET 5\%. Ta $2 / 1$

0,69043258 *

8. $12 \mathrm{P} /(100 \times 1) . \mathrm{d} / 26 \mathrm{~d} / 7 . \mathrm{ET} 5 \%$. Ta $2 / 1$

$0,61826593^{*}$

9. $1 / 2 s \cdot d / 26 d / 7$

$-0,37060168 n . s$.

n.s. - não significativo ao nível de 5\% de probabilidade pelo teste "t".

* - significativo ao nivel de $5 \%$ de probabilidade. 


\subsection{CONTEÚdo DE BORRACHA SECA (DRC)}

Uma anälise do conteūdo de borracha seca no láa tex è apresentada na tabela 15. Devido a insuficiência no nümero de repetições observadas em cada trátamento, não foi possivel a realização de um teste de mëdias para melhor compa ração. O valor mais alto encontrado para DRC foi de 31,8 , sendo este correspondente a sangria convencional. Maiores valores de DRC para a sangria em espiral, quando comparado à sangria por puntura, foram reportados por LEONG e TAN (1977), enquanto HASHIM et alii (1979), encontraram resultados opostos; WAIDYANATHA e ANGAMMANA (1981), compararam valores obtidos com os dois métodos de sangria e näo encontraram diferença significativa.

Tabela 15. Conteüdo de borrachá seca no látex (DRC) em relação aos diferentes mëtodos de sangria.

1. $6 p /(70 \times 1) . d / 26 d / 7 . E T 2,5 \%$. Ta $1,5 / 1$

30,3

2. $12 p /(70 \times 1) . d / 2$ d6/7.ET 2,5\%.Ta $1,5 / 1$

29,6

3. $6 \mathrm{p} /(70 \times 1) \cdot d / 26 d / 7 . E T 5 \% . T a 1,5 / 1$

30,1

4. $12 p /(70 \times 1) \cdot d / 26 d / 7$. ET 5\%.Ta $1,5 / 1$

29,2

5. $6 P /(100 \times 1) \cdot d / 2 d 6 / 7$.ET 2,5\%.Ta $2 / 1$

30,7

6. $12 p /(100 \times 1) . d / 26 d / 7$.ET 2,5\%. Ta $2 / 1$

30,3

7. $6 p /(100 \times 1) . d / 26 d / 7$. ET 5\%.Ta $2 / 1$

29,2

8. $12 p /(100 \times 1) . d / 26 d / 7$. ET $5 \%$. Ta $2 / 1$

29,9

9. $1 / 2 s \cdot d / 26 d / 7$

31,8 


\subsection{REA̧ÕEs da CASCA AO MÉTODO DE SANGRIA}

Resultados da avaliação final dos painëis de sangria são apresentados na tabela 16 . As reações da casca à sangria por puntura são apresentadas distintamente. A sangria convencional foi avaliada quanto ao consumo de casca, le sões provocadas com o uso da faca jebong, e quanto ao estado geral do painel.

\subsubsection{Espocamento de casca}

Foi observado em plantas submetidas a SPP (figura 6a), notadamente naquelas onde foram realizadas 12 puntu ras; dos quatro tratamentos com 6 punturas, apenas um apresentou duas plantas com espocamento, indicando que esse problema pode ser minimizado com a redução no nümero de punturas por faixa. 0 espocamento teve ocorrēncia restrita aos quatro meses apös início da sangria. As punturas foram realizadas com o estilete em posição oblíqua, näo sendo isso suficiente para reduzir o problema de espocamento. Com o passar dos meses, a casca tornou-se mais espessa facilitando a realização de faixas suficientemente profundas, com a consequente elimina ção de grande parte da casca dura. Segiu-se a realização de punturas com menor esforço à penetração e retirada do est lete, eliminando-se assim o problema de descolamento de casca e consequente espocamento. A causa deste problema, tal como descrito, foi acertadamente explicada por MORAES (1985). 

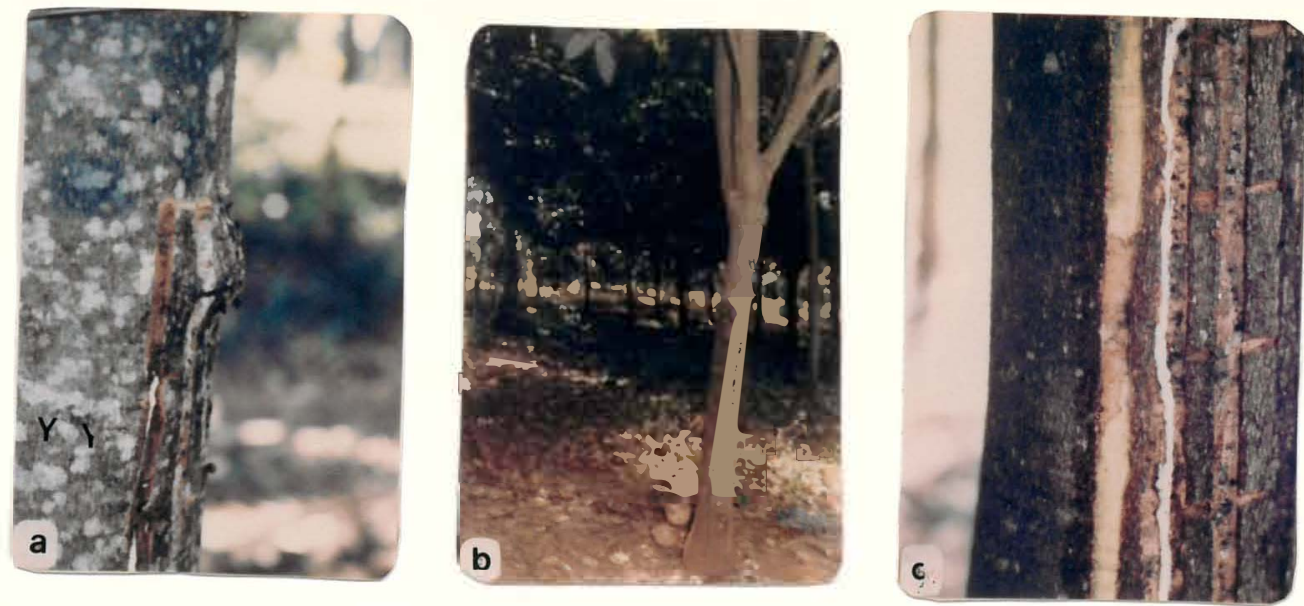

Figura 6. a - espocamento de casca; b - lesão vertical ao lon go do painel da SPP; c - secamento de painel.

Nas plantas que apresentaram o problema de espocamento, com a eliminação dos fragmentos de casca e remoção dos coāgulos de borracha, verificou-se regeneração parcial da casca após 8 meses.

\section{5 .2 . Lesão vertical}

Na ültima avaliação dos painēis apōs ll meses de SPP, com a remoção do tecido morto que cobria a casca em regerıeração, verificou-se a ocorrência de uma lesão no sentido da faixa vertical e com plena exposição do lenho (figura 6b). As faixas atingidas correspondiam ao quarto e/ou quinto meses de sangria, sendo as. mesmas abertas e exploradas res pectivamente nos meses de abril e maio. Não foram observados 
sintomas decorrentes da ação de patögenos. Com o crescimento secundārio do caule, ampliou-se a região de separação dos tecidos da casca, possibilitando uma maior exposição do lenho, formando uma lesão ao lonģo da faixa. Cerca de seis meses após, observou-se uma cicatrização parcial da região atin gida, com redução da lesão.

Numa anälise dos fatos, procurou-se admitir co mo causa, um dos fatores a seguir: a) incisão realizada ao longo da faixa raspada visando a realização de um sulco para estabelecer melhor tensão entre o látex e a canaleta; o uso inadequado da faca jebong possibilitou o atingimento do lenho dando formação à lesão no sentido de abertura da faixa; b) tor ção e flexão sob ação de vento forte provocando pequenos fendilhamentos longitudinais da casca, mal visíveis a olho nü, como observado por MORAES (1985); c) a ocorrência de um prolongado período seco durante os meses de maio a setembro, com a consequente redução do potencial hídrico das cëlulas dos te cidos da casca, seguido da ocorrência de chuvas a partir de outubro, quando, devido a grande diferença de potencial hídrico existente entre o solo e as cëlulas da raiz, procedeu-se imediata absorção de àgua pelas plantas, promovendo um rāpido a umento do volume celular com expansão irregular dos tecidos, sendo que aqueles menos consistentes, notadamente os localiza dos na região de abertura das faixas, sentiram mais drastica mente as alteraçōes de volume, sofrendo rachaduras.

A primeira hipōtese foi recentemente analisa- 
da em um seringal localizado en: São José do Rio Preto, São Paulo, onde observou-se que a lesão não recrudesceu e a regeneração da casca vinha se processando normalmente aos três meses apōs a ocorrência. A segunda hipótese é descartada devido a clara percepção e grande dimensão da lesão, mesmo meses após a sua ocorrência. A ültima hipótese constitui-se co mo causa mais provável. CHEE (1984), verificou um problema semelhante em um seringal nas proximidades de Vitöria, no Espírito Santo, após ocorrerem 9 meses de seca, seguidos de um período chuvoso. Nesse caso, entretanto, registrou-se a ação de Botryodiplodia e Fusarium.

\subsubsection{Inchaço}

Algumas plantas submetidas a SPP apresentaram este tipo de reação, mas a sua ocorrência não teve nenhuma consequência à sangria. Em alguns casos o inchaço foi devido ao atraso na prática de desbrota quando do periodo de desenvolvimento do seringal.

\subsubsection{Lesão paralela ao corte}

Esta avaliação foi feita nas plantas submetidas à sangria em meia espiral, onde observou-se, em sua grande maioria, a ocorrência de lesōes mecânicas motivadas pela utilização de uma casca menos espessa e realização de cortes 
às vezes muito pröximos do lenho. 0 comprimento das lesões variou de 5 a $30 \%$ da seç̧ão total. As lesões tiveram frequên cias variäveis ao longo dos 11 meses da sangria. Não foram registradas doenças de painel, mesmo não se procedendo o controle preventivo.

\subsubsection{Regeneração de casca}

Na tabela 17, são apresentadas algumas caracte rísticas estruturais observadas em amostras da casca regenera da em comparação à casca virgem, no mesmo método de sangria. No geral, a casca regenerada apresenta-se menos espessa, com maior nümero de anéis de vasos laticíferos e menor espessura de cēlulas pétreas.

Na SPP, os danos causados pela puntura são tem porärios e os ferimentos são logo fechados por tampões de làtex que têm função protetora; as células adjacentes à região atingida, notadamente àquelas localizadas na periferia, tambēm são afetadas; entretanto, as mesmas são protegidas do deterioramento e dessecação. A partir destas zonas periféricas, o felogênio divide-se, reconstituindo a periderme. Com o tempo, as cēlulas mais externas vão sendo impregnadas de lignina e suberina, formando as células pétreas, as quais tendem a circundar a zona ferida. Com a remoção do tecido morto que recobre o tronco à altura do painel, observa-se uma nova casca cuja camada externa é constituída de tecidos da periderme e 


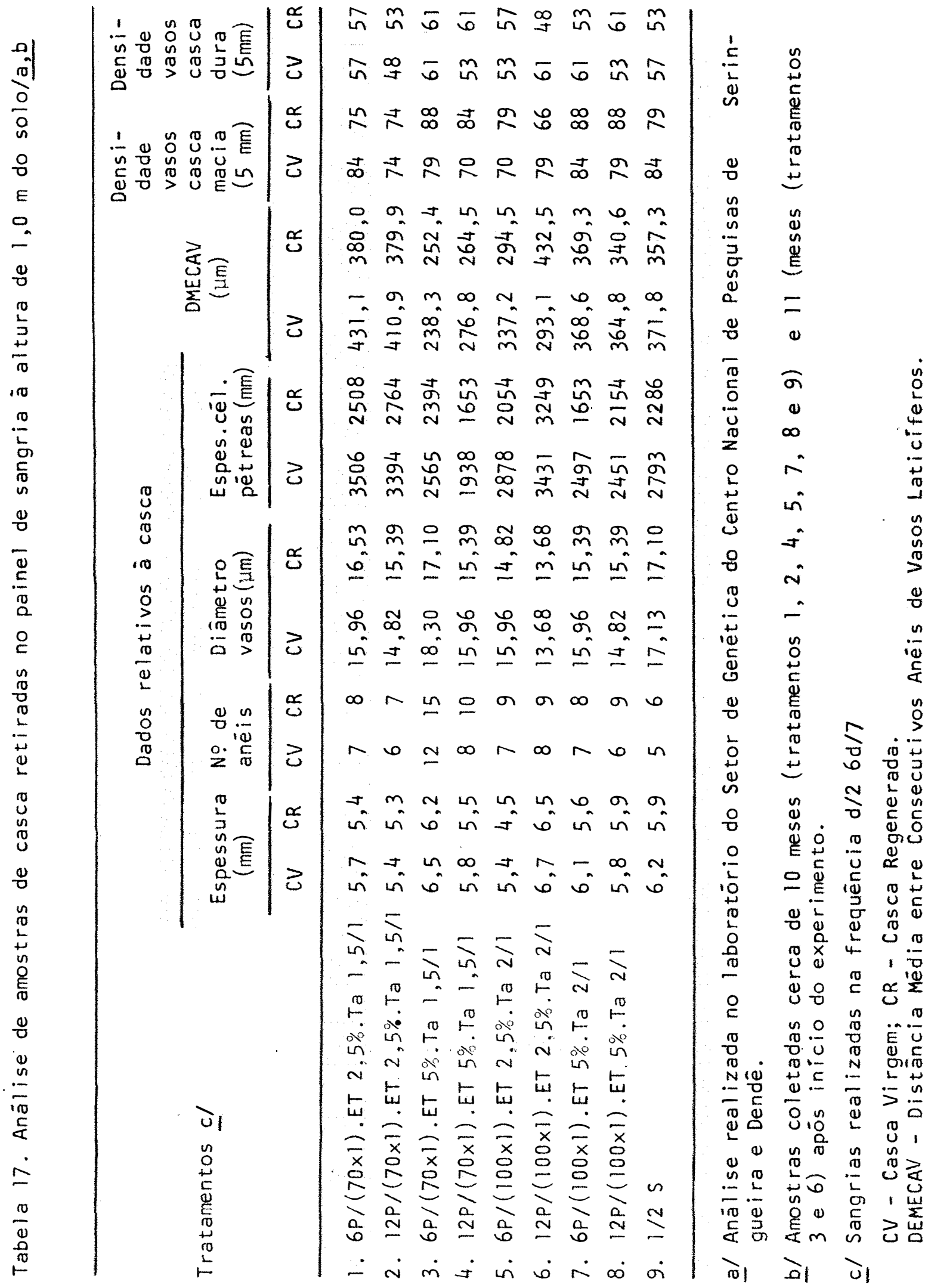


cēlulas pétreas. 0 cãmbio vascular não é totalmente afetado pela puntura e a remoção dos tecidos internos da casca se pro cessa normalmente; os vasos laticíferos são iniciados a partir da diferenciação de cēlulas do floema. A princípio, a re gião atingida pela puntura apresenta um espaço vazio, mas com o tempo, dä-se a reconstituição normal dos vasos laticíferos. Neste trabalho, mesmo com o registro dos danos mencionados, a situação dos painēis demonstra-se favorāvel à futura exploração da casca regenerada. As plantas submetidas à sangria por puntura estarão aptas a futura exploração através uso da sangria em espiral, cerca de 24 meses após início da SPP.

As plantas submetidas a sangria em meia espiral tiveram um consumo mëdio de casca em torno de $25 \mathrm{~cm}$ em 11 meses de exploração, estando dentro dos padrões convencionais para o sistema; a exploração das mesmas poderá ainda ser realizada em casca virgem do painel "A" e no painel "B", quando a casca presentemente utilizada, encontrar-se-á plenamente regenerada.

\subsection{Secamento de painel}

Foi registrado em apenas uma planta submetida a SPP (tabela 16): O sintoma ocorreu em torno de duas punturas em uma faixa de $70 \mathrm{~cm}$, onde realizou-se 6 furos (figura 6c). Nos demais pontos dessa mesma faixa, havia flu- 
xo de látex e com a exploração das faixas seguintes o problema não foi mais observado. 


\section{CONCLUSÕES}

Com base nos resultados obtidos neste trabaIho, observaram-se as seguintes conclusões:

1. Atravēs da sangria por puntura, pode-se promover a antecipação de uma produção compensadora no período que antecede ao início da sangria convencional.

2. A produção do melhor tratamento na SPP (6P) $(70 \times 1) . d / 26 d / 7$.ET $5 \%$. Ta 1,5/1), é cerca de $29 \%$ superior àquela obtida pela exploração precoce da sangria em meia espiral $(1 / 2 s \cdot d / 26 d / 7)$.

3. As produções obtidas nos seis primeiros meses da SPP são consideradas baixas em comparação aos meses subsequentes; isto sugere a utilização de uma maior concenträ ção de estimulante no semestre inicial. 
4. Na avaliação dos tratamentos da SPP, verificou-se que:

- A concentração do estimulante é o mais impor tante fator determinante da produção.

- Ethephon 5\% possibilita maiores ganhos em produção, notadamente quando em faixa de $70 \mathrm{~cm}$, sendo as faixas de $100 \mathrm{~cm}$ prejudicadas pelas perdas por escorrimento de látex para fora da canaleta; este problema também motivou a redução no desempenho da mão-de-obra.

- Sob condições de menor concentração do estimulante (ethephon $2,5 \%$ ), o incremento na ärea de drenagem ë compensado pelo maior comprimento de faixa, havendo neste caso, menores perdas por escorrimento de lätex face ao menor volume produzido em relação ao correspondente à maior concentração de ethephon.

- Diante do maior nível de produção motivado pelo adequado uso da concentração do estimulante (ethephon $5 \%$ ) e comprimento de faixa onde não há perda excessiva de lätex para fora da canaleta, não hä diferença entre a realização de 6 ou 12 punturas; neste caso o menor nümero de punturas è mais vantajoso do ponto de vista operacional, além de reduzir os riscos de danos à casca.

- Não foi observado diferença estatística quan to ao crescimento do tronco em plantas submetidas à sangria em meia espiral quando comparado a quase totalidade das plantas submetidas à sangria por puntura; entretanto, as plantas 
do tratamento 3 (SPP) tiveram um crescimento inferior à sangria convencional.

- Na sangria por puntura a produção na quarta semana apōs estimulação atinge ríveis desprezíveis; em vista disto, deve-se optar pela paralização da tarefa, nesse período, promovendo melhor utilização do seringueiro.

- Entre as reações da casca à SPP, observa-se que o espocamento de casca è um sērio problema, mas, passível de ser minimizado com a realização de um menor nümero de punturas e com a abertura de faixas suficientemente profundas; a lesão vertical é o principal dano observado no painel de sangria, como consequência do uso da SPP sob condições de adversidades climāticas no decorrer da fase de exploração.

- Aos ll meses apōs submetida à SPP, a casca apresenta satisfatōria regeneração, demonstrando condições pa ra subsequente exploração cerca de 24 meses apös início da sangria precoce.

5. Na sangria em espiral, embora utilizando-se plantas com casca pouco espessa, a regeneração vem se proces sando normalmente.

6. 0 conteüdo de borracha seca (DRC) na sangria em espiral foi ligeiramente superior ao obtido nos tratamentos da SPP. 
7. A SPP é um mëtodo alternativo para sangria precoce, embora não seja uma solução irrestrita; face aos pró blemas apreciados, novos métodos $(1 / 4 \mathrm{~s} . \mathrm{d} / 3 \mathrm{~d} / 4.11 \mathrm{~m} / 12 . \mathrm{ET} 2,5 \%$. 8a. ou $1 / 2 \mathrm{~s} . \mathrm{d} / 7.11 \mathrm{~m} / 12$.ET $2,5 \% .8 / \mathrm{a}$, com e sem balanceamento anual de painell devem ser estudados de forma comparada, visan do a definição de uma técnica que possibilite adequado crescimento da planta, satisfatōrias produções, economia de mãode-obra e minimização de danos à casca. 


\section{LITEPATUPA CITADA}

ABRAHAM, P.D., 1980a. Introduction of exploitation of Hevea.

In: RUBBER RESEARCH INSTITUTE OF MALAYSIA training manual on tapping, tapping systems and yield stimulation of Hevea. Kuata Lumpur, p. $1-15$.

ABRAHAM, P.D., 1980b. Responses of Hevea cultivars to exploi* tation. In: RUBBER RESEARCH INSTITUTE OF MALAYSIA training manual on tapping, tapping systems and yield stimulation of Hevea. Kuala Lumpur, P.130-141.

ABRAHAM, P.D. e J.L. ANTHONY, 1981. Prospects of micro tappling immature rubber. In: Proceedings of Rubber Research Institute of Malaysia Planter's Conference. Kuala Lumpur, p.93-111.

ABRAHAM, P.D.; P.R. WHICHERLEY e S.W. PAKIANATHAN, 1968. Stimulation of latex flow in Hevea, brasiziensis by 4-amino- 3 , 5,6-trichlorophicolinic acid and 2-chloroethane phosphonic acid. Journal of the Rubber Research Institute of Malaysia. Kuala Lumpur, 20:291-305. 
ABRAHAM, P.D.; J.L. ANTHONY; J.B. GOMEZ; S. SIVAKUMARAN e 1. HASHIM, 1979. Towards automated tapping of Hevea. In: Proceedings of Rubber Research Institute of Malaysia Planter!s Conference. Kuala Lumpur, p.182-200.

ABRAHAM, P.D.; J.W. BLENCOWE; S.E. CHUA; J.B. GOMEZ; G.F.J. MOIR; S.W. PAKIANATHAN; B.C.SEKHAR; W.A. SOUTHORN E P.R. WICHERLEY, 1971. Novel stimulants and procedures in the exploitation of Hevea. 11. Pilot trial us Ing 2-chloroethylphosphonic acid (ethephon) and acetylene with various tapping systems. Journal of the Rubber Research Institute of Malaysia. Kuala Lumpur, 23:90-113.

BERNARDES, M.S.; G.C. SANTOS E R.S. SIQUEIRA, 1986. Beneficiamento, mercado e politica da borracha natural. In: Simpósio sobre a ciltura da seringueira no Estado de São Pau10, Piracicaba, Fundação Cargill, p.317-333.

BINGZHONG, H.; W. JILLH eY. CHUNING, 1981. Effect of ethrel on cambial activity in Hevea brasiliensis. Chinese Journal. of Tropical crops, South China, 2(1): 70-75.

BOATMAN, S.G., 1970. Physiological aspects of rubber trees.

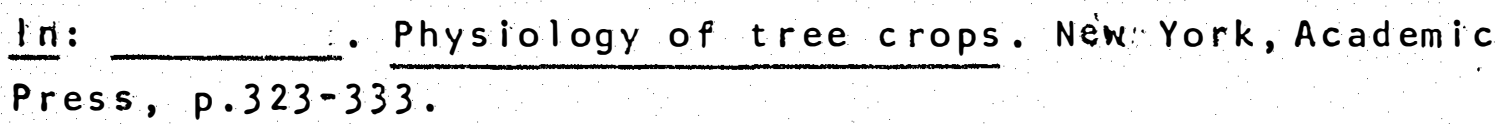

BUTTERY, B.R. E S.G. BOATMAN, 1967. Effects of tapping wounding and growth regulators on turgor pressure in Hevea brasiliensis Muell Arg. Journal Experimental Botany, London, 18(57): 644 .

BUTTERY, B.R. e S.G. BOATMAN, 1976. Water deficit and flow of latex. In: Kozlowski, T.T. Water Deficits and Plant. Growth. New York, Academic Press, p.233-389. 
CAMARGO, M.B.P.; R.R. ALFONSI; A.A. ORTOLANI; M.J. PEDRO JUNIOR; O. BRUNINI E O.M.D.P. CHIAVEGATO, 1986. A seca de 1985 no Estado de São Paulo. O Agronómico. Campinas, 38(1): $31-44$, jan/abr.

CARDOSO, M.,1985. Seringueira. Boletim Té̉cnico. Instituto Agronômico, Campinas (100): 85 .

CHEE, K.H., 1984. Report advisory visit to Vitöria. Brasilia, SUdHEVEA, Ilp. (Circulação interna).

COLINA. Prefeitura Municipal, 1985. Caracteristicas gerais do Municiplo de Colina. Colina, SP. 4p. (datilografado).

DIJCKMAN, M.J., 1951. Hevea; thirty years of research in the Far-East. Coral Gables. Flärida, University of Miami press. $329 p$.

FERWERDA, F.P. E F. WIT, 1969. Rubber: Hevea brasiliensis (Wild) Muell. In: _ Outlines of perennial crop breeding in the tropics..Washington, p.427-458.

GENER, P.; L. PRIMOT e J. TUPY, 1977. Recents progress in microtapping. Rêvue Gēnērale des Caoutchoucs et Plastiques, Paris, 54 $(569): 141-143$.

GOMES, A.R.S., 1979. Latex flow in Hevea Brasiliensis. Madison, University of Wisconsin. 27p.

GOMES, A.R.S. A A.C. VIRGENS FILHO, 1984. Sangria da seringueira (Hevea sp.) no Sul da Bahia: situação atual e futuras estratëgias. In: IV Seminärio Nacional da Seringueira. Salvador, SUDHEVEA, P.93 (Resumo dos Trabalhos).

HANZAH, S.H. e J.GOMEZ, 1981. Anatomy of bark renewal in normal puncture tapped rubber trees. Journal of the . Rubber Research Institute of Malaysia. Kuala Lumpur, 29(2): 86-95. 
HASHIM, 1.H., 1980. Microtapping. In: Rubber Research Institute of Malaysia training manual ontapping, tapping systems. and stimulation of Hevea. Kuala Lumpur, p.84-100.

HASHIM, I.H.; T.C.P.NG; O.K. CHEW; P.D. ABRAHAM E J.L. ANTHONY, 1979. Microtapping and the development of Micro-X system. In: Proceedings of Rubber Research Institute of Malaysia Planter's Conference, Kuala Lumpur, p.128-159.

INSTITUT DES RECHERCHES SUR LE CAOUTCHOUC, Abdijan, Côte d' Ivoire, 1978. Essai d'exploitation precoce en saignẻe par piqueres sur GT I et RRIM 600 . In: mier semestre 1978. Côte d'lvoire, p.37-40.

INSTITUT DES RECHERCHES SUR LE CAOUTCHOUC, Alidijan, côte d' Ivoire, 1980. Saignêe par piquere: influence de la profundeurde saignêe. In: Rapport du premier se= mestre 1980. Côte d'lvoire, p.35-40.

LEONG, T.T. e H.T. TAN, 1977. Result of Chemara puncture tapping trials. In: Proceedings of Rubber Research Institu te of Malaysia Planter's Conference, Kuala Lumpur, P. Mll134.

LEONG, T.T.; A.A. RAVQOF e H.T. TAN, 1977. Potentials of punc ture tapping. In: Proceedings of Rubber Research institute of Malaysia Planter's: Conference, Kuala Lumpur, p. 297307 .

LUCKMAN, 1983. Revised international notation for exploitar tion systems. Journal of the Rubber Reseapch institute of Malaysia. Kuala Lumpur, 31(2): $130-140$. 
LUCKMAN, 1984. Allongment de la vie économique de l'Hevea par le systems d'exploitation. In: Colloque International. "Exploitation-Physiologie et Amëlioration de l'Hevea Mont:pellier, France, 1984. Compte-rendu. Montpellier, IRCA, P. $339-356$.

LUSTINEC, J. e W.L. RESING, 1965. Methods for delimitation of the flow area by micro-tapping and radio-isotopes. Planter's Bulletin of the Rubber Research lnstitute of Malaysia. Kuala Lumpur (8): 144-149.

MENEZES, J.A. S. A A.P. VASCONCELOS FILHO, 1977. Borracha vegetal; perspectivas de mercado e algumas consideraçôes econômicas, biolögicas e polîticas. Ilhëus, CEPLAC/ CEPEC. 31P. (Boletim Tëcnico, 54).

MORAES, V.H.F., 1980. Segmento de fisiologia. In: VII Curso de Especialização em Heveicultura, Belêm, SUDHEVEA/FCAP, $50 p$.

MORAES, V.H. F., 1981. Deslocamento de casca do painel na. sangria por puntura. Manaus, EMBRAPA/CNPSD. 3 p. (Resquisa em andamento, 8).

MORAES, V.H. F., 1284. Resposta de clones amazônicos $a$ sangria precoce por punturas. In: IV Seminärio Nacional de Seringueira, Salvador, SUDHEVEA, p.91. (Resumo dos tra balhos).

MORAES, V.H. F., 1985. Sangria precoce por punturas. Manaus, EMBRAPA/CNPSD. 35p. (Circular Técnica, 6).

NG, C.S.; A.P. NG e P.K. YOON, 1972. Economics of early opening. In: Proceedings of Rubber Research Institute of Malaysia Planter's Conference. Kuala Lumpur, p.34-35. 
ORTOLANI, A.A.; M.J. PEDRO JUNIOR; R.R. ALFONSI; M.P.B. CAMAR Go e 0. BRUNINI, 1983. Aptidão climática para regionalizá ção da heveicultura no Brasil. In: Anais do I Seminärio Brasileiro sobre Recomendações de Clones de Seringueira. Bra silia, SUDHEVEA, p.19-28.

PARAJONTHY, K., 1980. Brown bast and exploitation of dry trees. In: RUBBER RESEARCH INSTITUTE OF MFLAYSIN training manual on tapping, tapping systems and yiéld stimulation of Hevea.

Kuala Lumpur, p.55-65.

PARAJONTHY, K.; J.B. GOMEZ E H.Y. YEANG, 1975. Physiological aspects of brown bast development. In: Proceedings of Rubber Research Institute of Malaysia Planter's Conference. Kuala Lumpur, p.1-22.

PIMENTEL GOMES, F., 1976. Curso de estatística experimental. 6. ed. São Paulo, Livraria Nobel. 430 .

POLHAMUS, L.G., 1962. Rubber, botany production and utiliza= tion. London, Leonard Hil!. $449 \mathrm{p}$.

PRIMOT, L.; M. TONNELIER e J. TRANCARD, 1978. A saignēe par. plqueres; bilan de annëes d'êtude à l'IRCA; perspectives. d'avenir. Côte d'lvoire, IRCA. $35 \mathrm{p}$.

RAMACHANDRAN, P. e T.P. LEE, 1979. Preliminary results of Socfin puncture tapping trials. In: Proceedings of Rubber Research Institute of Malaysia Planter's Conference. Kuala Lumpur, p.166-181.

REIS, A.C.F., 1953, O seringal e o seringueiro. Rio de Janeiro, Ministërio da Agricultura, SIA. $194 \mathrm{p}$.

RUBBER RESEARCH INSTITUTE OF INDIA, 1980. Handbook of natural rubber production in India. Kottayam. $668 \mathrm{p}$. 
SARAMANAYAKE, C, 1985. Puncture tapping of Hevea trasizien sis in comparison with conventional excision tapping - Sri Lanka experience. In: International Rubber Conference, Kuala Lumpur, $17 \mathrm{p}$.

SETZER, J., 1966. Atlas climâtico e ecolögico do Estado de São Paulo. São Paulo, Comissão Internacional da Bacia do Parana - Uruguai/CESP. 61 p.

SILVEIRA, J.A.G. da, 1979. Tecnologia da borracha: determinaçôes analiticas de rotina no lätex de Hevea. In: VI Curso de Especialização em Heveicultura, Belëm, SUDHEVEA/fCAP, $15 p$.

SIVAKUMARAN, S. e J.B. GOMEZ, 1980. Puncture tapping-an over view. Planter's Bulletin. Kuala Lumpur, 164: 101-111.

SIVAKUMARAN, S. e J.B. GOMEZ, 1981. Evaluation of puncture tapping as a method of exploitation of Hevea. In: Symposium International Rubber Research and Development Boards, Hat Yai. 13p. (Preprint)

SOARES, W.0., 1985. Têcnica da sangria por puntura em dois clones de seringueira (Hevea sp.). Viçosa, 42p. (Mestrado - Universidade Federal de Vif̧osal.

SOARES, W.O. e F.S.V. PINHEIRO, 1984. Influência da sangria por puntura no desenvolvimento da seringueira. In: IV Seminärio Nacional da Seringueira, Salvador, SUDHEVEA, P. 92 (Resumo dos trabalhos)

SouzA, R.F., 1984. Pesquisas para o desenvolvimento da hevei vultura no Brasil. Palestra proferida no "IV Seminärio $\mathrm{Na-}$ cional da Seringueira", Salvador, 1984. Salvador, 48p. (da t i lografadol. 
SPIEGEL, M.R., 1978. Anālise da variância. In: - $\stackrel{\text { Pro- }}{-}$ babilidade estatistica. Trad. de Alfredo Alves de Farías. São Paulo, McGraw-Hill, cap. 9, p.435:480.

STEEL, R.G.D. e J.H. TORRIE, 1980. Principles and procedures. of statistics; a biometrical approach. New York, McGrawHill. $633 \mathrm{p}$.

SUDHEVEA, 1984. Relatório de atividades. Brasilia $M / C /$ SUDHEVEA, $74 p$.

SYPE, H.V., 1984. The dry cut syndrome of Hevea brasiliensis; evolution, agrononical and physiogical aspects. In: Colloque International "Exploitation - Physiologie et Amélioration de l'Hevea, Montpellier, France, 1984". Compte-rendu. Montpellier, IRCA, P.249-271.

THIM, L.T.; A.A. RAVOOF e T.H. JONG, 1979. A preliminary report on exploitating rubber through puncture tapping. In: Proceedings of RRIM Planter's Conference. Kuala liumpur, P. 209-215.

TONNELIER, M.; L. PRIMOT; 4. TRANCARD E H. OMONT, 1979. La saignêe par piquere. Bilan provisoire et perspectives d' avenir. Révue Gènèrale des Coutchouc et Plastiques. Paris, 59(4): $71-75$.

TUPY, J., 1973a. Possibilitê d' exploitation de l'Hevea par micro saignēe. Révue Gënërale des Caoutchouc et Plastiques. Paris, $\underline{50}(7): 620-623$. 
TUPY, J., 1973b. The activity of latex invertase and latex. production in Hevea brasiliensis Muell Arg. Physiologie Vegetale, Abidjan, $\underline{11}(4): 633-641$.

TUPY, J., 1984. Transport, utilisation et disponibilite du saccharose en relation ayec la production chez l'Hevea. In: Collogue International "Exploitation - Physiologie et Amélioration de l'Hevea, Montpellier, France, 1984". Compterendu, Montpellier, IRCA, p.135-153.

VERNOU, P. e M. TONNELIER, 1985. Production de l'Hevea effect nefaste d'une saignêe precoce. Révue Gênérale des Caoutchouc et Plastiques, Paris (654): 89-93.

VIRGENS FILHO, A.C. E P.R.C. CASTRQ, 1986. Sangria da Seringueira (Hevea sp.). In: Simpósio sobre a cultura da seringueira no Estado de São Paulo, Piracicaba, SP, Fundação Cargill, $p .271-315$.

WAIDYANATHA, U.P.S., 1985. Report on activities and recomendation. IIhës, IICA/EMBRAPA/CEPLAC, $92 p$.

WAIDYANATHA, U.P.S. E D.K. ANGAMMANA, 1981. Early Exploitation of Hevea rubber trees by puncture and short cut tappings. Expl. Agric. Dartonfield, 17:303-30.9.

WENXIAN, $X$. e F. JINGUI, 1981. Studies on puncture tapping techinique and its effects or physiology of rubber tree. 1. Effect of puncture tapping on yield and physiological conditions of young rubber trees. Chinese Journal of Tropical Crops. South China, $2(1): 21-33$. 
WISNIEWSKI, A., 1979. Aspectos geopoliticos da heveicultura. In: Vr Curso de Especialização em Heveicultura, Belëm, SUDHEVEA/FCAP. $19 p$. 